\title{
Where the Global meets the Local: Managing Caves as Heritage Places within a Mining and Extractive Industry in the Lao PDR
}

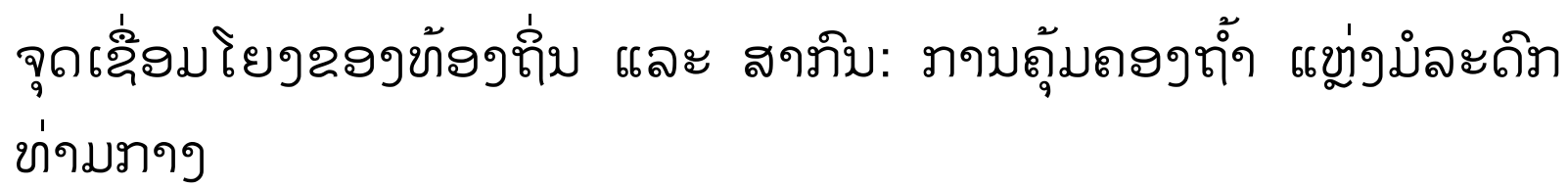

\author{
Nicholas Roberts \\ The Cairns Institute, \\ Division of Research \& Innovation, \\ James Cook University, Cairns Campus, Australia \\ Correspondence: \\ nicholas.roberts@jcu.edu.au
}

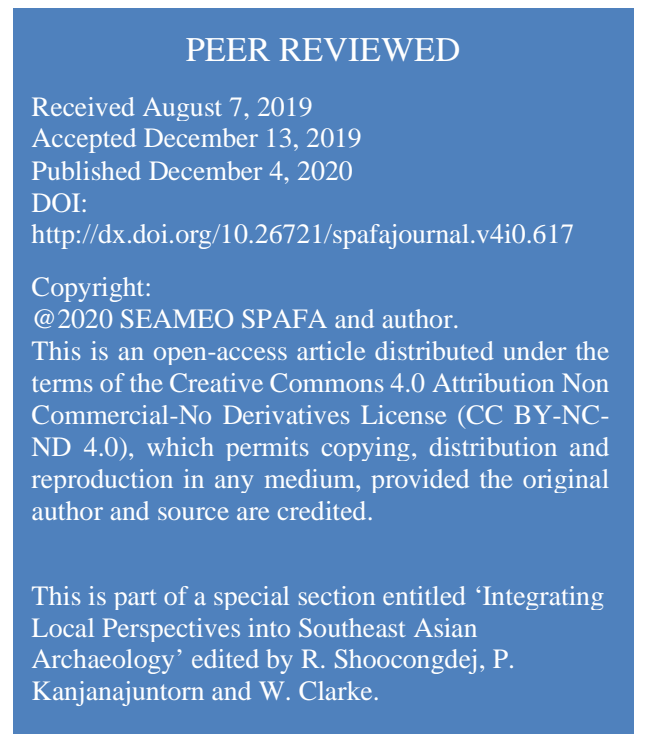

\begin{abstract}
Caves meet many unique human and cultural needs as a geological component of local ecology. Within Vilabouly District, Savannakhet Province, southern Lao PDR, caves and their surrounding environments are identified to hold multiple uses and values for local Phou Tay and Brou ethnolinguistic groups. Caves hold overlapping and interdependent uses and values between the past, the present, and the future, and can be considered as 'living' and often 'sacred' natural places. Establishment of the Sepon Gold \& Copper Mine (Sepon Mine) in Vilabouly District during the early 21st century introduced a range of new ideas, uses, and values for caves via implementation of international regulations and 'best practice' for cultural heritage and environmental management. International definitions and practices for heritage management often prioritise tangible and singular values of heritage over multiple or interconnected uses and values, and meaningful engagement of the local community in management processes is often limited. At the Sepon Mine caves were predominately managed for geoheritage, biodiversity, and archaeological values, and mitigation efforts were challenged by complex and ineffective land-tenure arrangements. In this paper I examine the application of international heritage management practices as part of mining operations at the Sepon Mine between 2008 and 2015. Focusing on caves as 'heritage places' I consider the benefit and challenge to incorporate community needs and values in heritage managing process within mining operations. I conclude by proposing integration of regional heritage charters and protocols within mining and extractive industries in the Lao PDR and Southeast Asia, to encourage amalgamation of local, national, and regional beliefs and practices with international 'best practice' in the aim to develop more contextually relevant and sustainable heritage management and conservation practices.
\end{abstract}




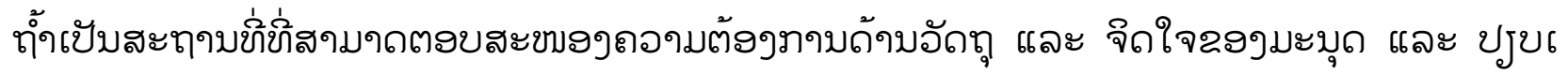

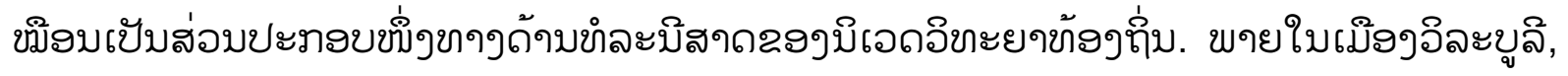

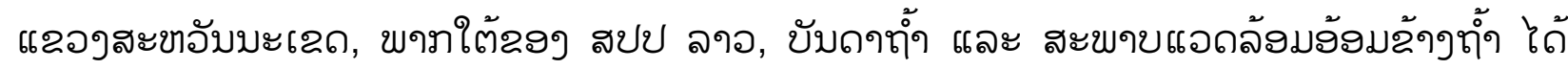

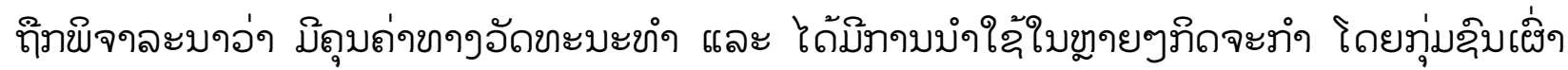

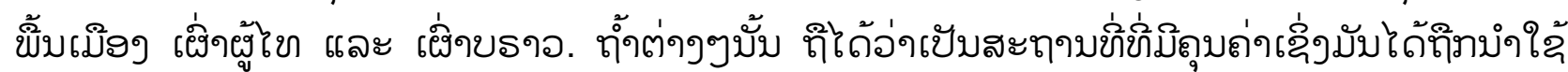

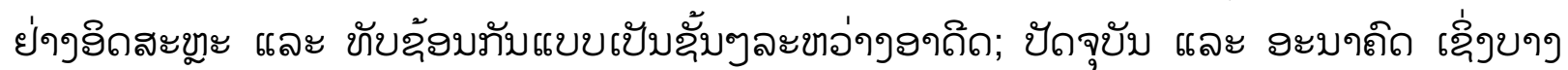

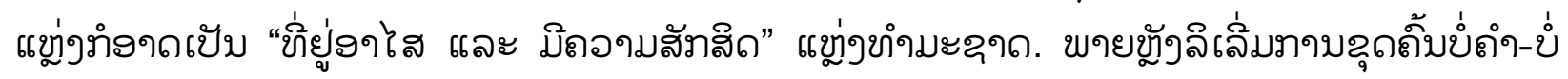

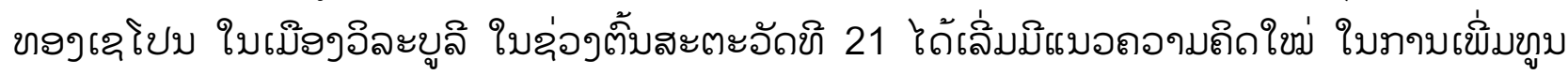

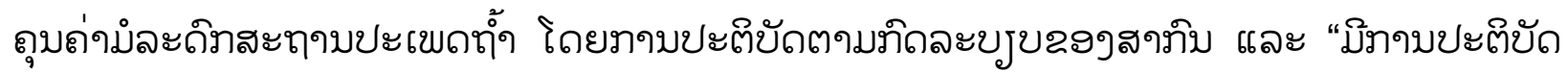

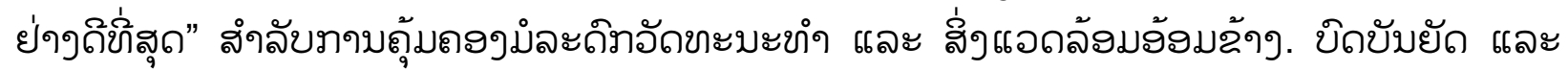

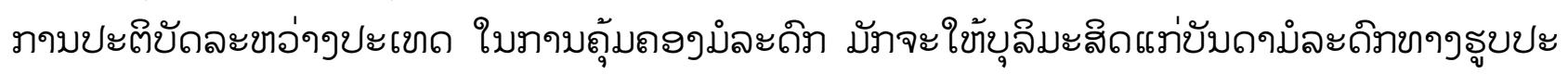

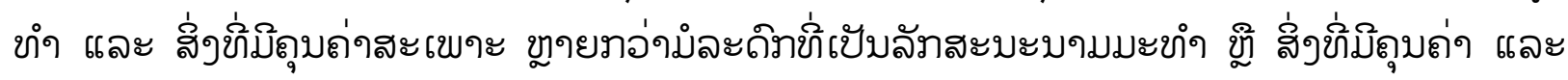

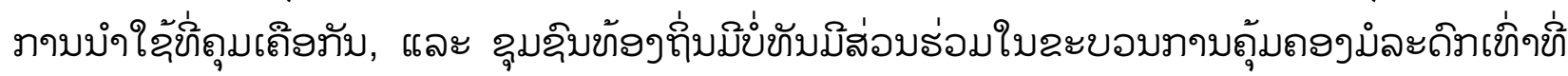

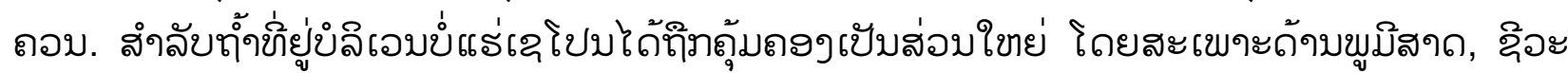

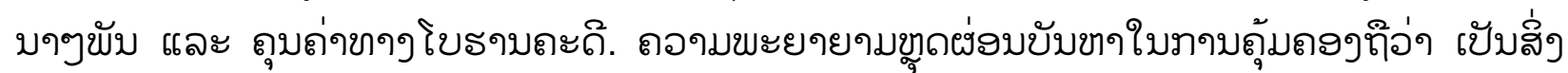

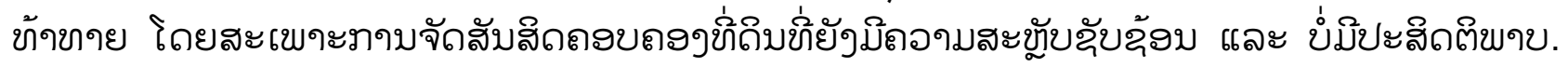

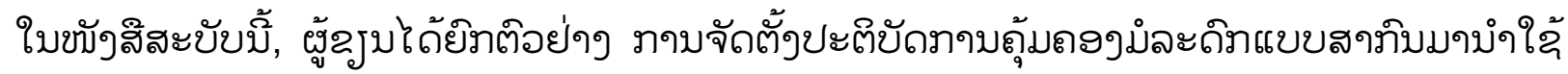

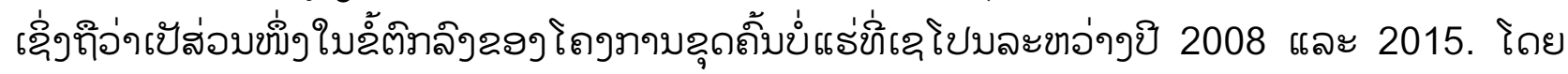

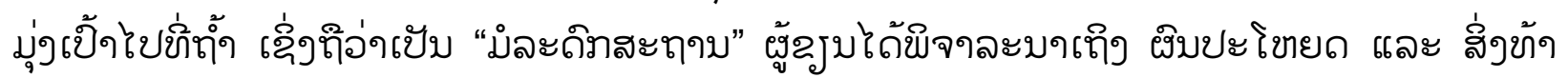

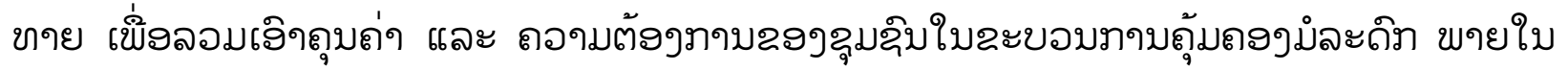

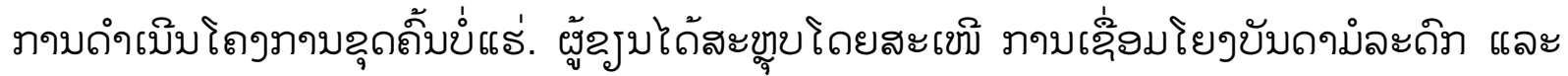

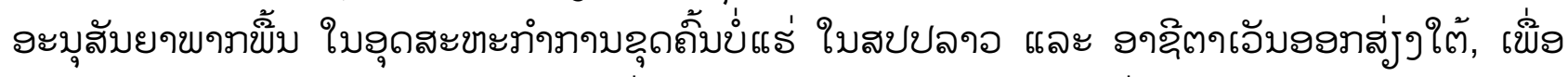

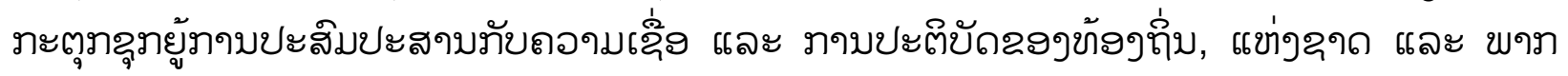

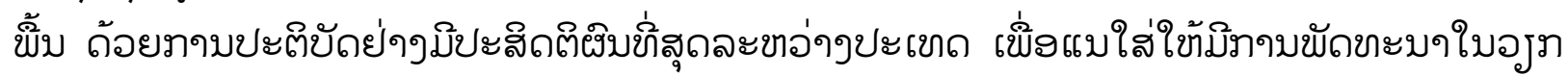

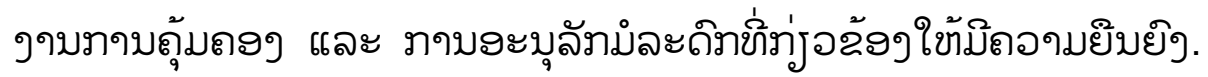

Keywords: Lao PDR; Sepon Gold \& Copper Mine; Commercial Heritage Management; Cave

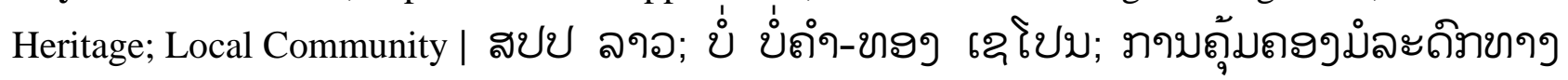
ภาบล้ๆ; มละล์ภ

\section{Background}


Caves meet many unique human and cultural needs as a geological component of local ecology (Kiernan 2011). Globally, caves (and also limestone karstic formations and rock shelters) are recognised to be highly integrated into human socio-cultural, spiritual, economic, and ritual practices (Waterton, Hamilton-Smith, Gillieson, \& Kiernan 1997). Karst, and their associated caves, represent a large variety of the planets geological diversity and are some of the oldest landforms on earth (Williams 2008). They are also highly significant biological ecosystems, supporting high levels of biodiversity and endemism, making them global biodiversity 'hotspots' (Clements et al. 2006; Culver \& Skeet 2000; Williams 2008). Cave and rock shelter sites contain evidence for some of the earliest hominin and human habitation, and the remains of extinct animal species (Bekken, Schepartz, Miller-Antonio, Hou 2004; Dirks \& Berger 2013). Caves and rock shelters are considered to have played a significant role in the development of human consciousness, art, religion and ritual, and mortuary practices (Lewis-Williams 2002; Mauret 2004, Tattersall 1998). Caves and karst continue to support human activities, including as a location or source for human economic and subsistence-based activities and religious and spiritual use (Waterton et al. 1997).

Today, caves often retain 'sacred' qualities, and remain places for 'living' human cultural and religious beliefs and practices built on several overlapping and interdependent historical, cultural and natural heritage values (Kiernan 2015; Roberts 2015; Verschuuren et al. 2010). It is through the variety of human uses and values found in caves (and rockshelters), and the long-term interaction between nature, culture, and society, that make these geological locations highly significant. Almost ironically, it is the variety of cross-cutting and interdependent uses and values caves hold which present challenges to sustainable management of them, and equally to other heritage places with 'mixed', 'living' and 'sacred' qualities (Kiernan 2011; Roberts 2015; Sidisunthorn et al. 2006). The significant and ongoing management challenge is not only to identify the full range of cross-cutting and interdependent uses and values caves hold, but to provide management approaches that promote and safeguard them for this variety of uses and values. In this paper I examine the management of caves as 'heritage places' within a mining and extractive industry. This will consider 1). the effectiveness of applying international heritage management 'best practice' to identify and manage caves as part of mining operations; 2). the benefit and challenges to incorporate community needs and values in heritage management process within mining operations; and 3). integration of regional heritage charters and protocols within heritage management process in mining and extractive industries in the Lao PDR and Southeast Asia to develop more contextually relevant and sustainable heritage management and conservation practices.

\section{Heritage Management and Mitigation Processes for Caves at the Sepon Mine}

\section{Caves as Heritage Places within the Sepon Mine}

Caves (and rock shelters) in Vilabouly District and Sepon Mine are identified to hold a range of uses and values that are often overlapping and interdependent for local Phou Tay and Brou ethnolinguistic groups. Caves (and rock shelters) form part of broader ecosystems and cultural landscapes and have undergone periods of continuity and change in how they are used and valued by human populations and cultural groups (Roberts 2019). Cultural and ecological uses and values have developed across thousands of years, with caves being incorporated in regional social, cultural, and economic activities for at least five centuries, but likely since the Neolithic period. Buddhist-use for and value in caves may be over 200 years old, and while Buddhist practices and material culture were largely phased out during the Vietnam War (also known as the American War) and Cultural Revolution periods, several caves today remain the location for Buddhist rituals and festivals. Many natural places and landforms in Vilabouly District have non-Buddhist sacred and mythological association to local villages, with several caves being the location for ancestral 
spirits, and sites for annual calendrical ritual and spiritual practices (Chamberlain 2007). Many natural sites which have spiritual values are contained within village landscapes, are largely administered by village customary law, and are central to local cosmology. Meaning placed in caves has developed as part of a broader process of place-making through historical process and cultural demarcation of the natural environment and man-made places. Continuity and change in uses and values of caves reflect transitions in local and regional social and cultural beliefs and practices over time (Roberts 2019).

Establishment of the Sepon Mine during the early 21st century introduced the process of cultural heritage and environmental management to Vilabouly District (see Figure 1). The application of heritage assessments, archaeological surveys, and ethnographic research as part of the mining process identified that caves and rock shelters within the Vilabouly District held a variety of significant natural and cultural values as 'heritage places' (Chamberlain 2007; Sayavongkhamdy \& Souksavatdy 2006; 2011). Caves, rock shelters, and karst areas were found to represent "a wide variety of archaeological and other heritage sites... within the project area" (Sayavongkhamdy \& Souksavatdy 2011: 1) and made up 20 of the 38 sites recognised as Cultural Heritage Sites, with 10 caves listed as Highly Significant Cultural Heritage Sites, and 6 caves considered Significant Cultural Heritage Sites (see Table 2). Caves and rock shelters were identified and managed for either prehistoric significance, Buddhist era occupation, and for their use during the Indochinese Wars (most notably the Vietnam War and later post-Revolutionary Period). Heritage assessments also identified that some caves are important ecological locations, mostly for their 'aesthetic qualities', and that caves share association with other water and hydrological systems. Sociocultural assessments identified that use of some caves in the Vilabouly remained ongoing, supporting economic, subsistence, and religious needs for some villages. Based on these assessments caves and their surrounding environments could be described as 'living' cultural places that were being managed for these values through spiritual or cultural practices and customary laws. Many caves in the Sepon Mine and Vilabouly District also display properties of Sacred Natural Sites (Verschuuren et al. 2010), defined as areas which "are in some way holy, venerated or consecrated and so connected with religion or belief systems, or set aside for a spiritual purpose" (p. 2). Notwithstanding that most caves within the Sepon Mine and broader Vilabouly District were identified to hold multiple cross-cutting and interdependent uses and values, they were generally managed for discreet natural heritage, or tangible, intangible or historical cultural heritage values within the heritage management framework. 


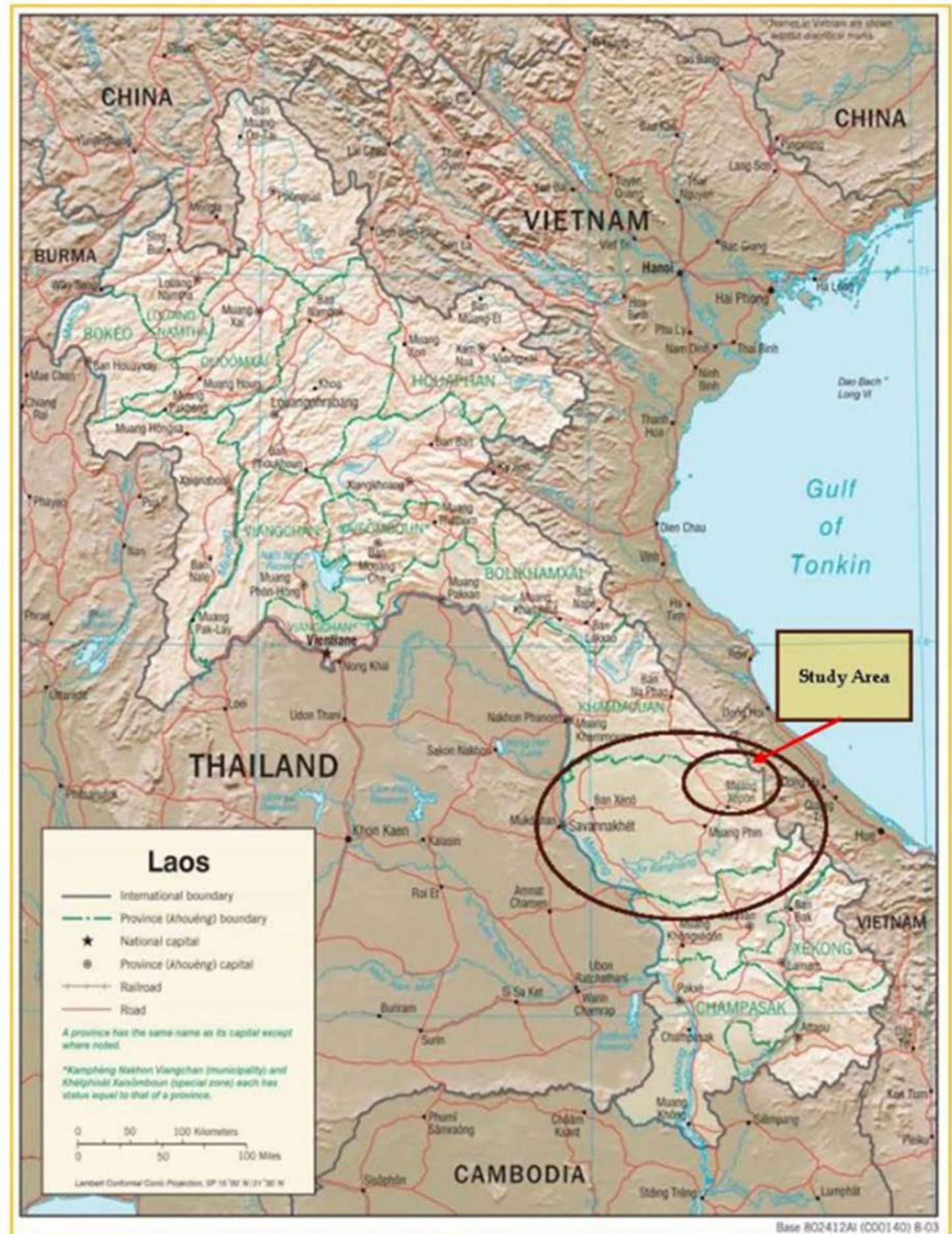

Fig. 1 Lao PDR and Vilabouly District, the location of the Study Area. Source: https://mapcruzin.com/free-laos$\underline{\text { maps.htm }}$

\begin{tabular}{|l|l|l|}
\hline Year & Law, Policy, Protocol or Regulation & Agency or Nation \\
\hline
\end{tabular}




\begin{tabular}{|c|c|c|}
\hline 1964 & Venice Charter & $\begin{array}{l}\text { ICOMOS (International Council for } \\
\text { Monuments and Sites) }\end{array}$ \\
\hline 1972 & $\begin{array}{l}\text { Convention Concerning the Protection of the World } \\
\text { Cultural and Natural Heritage }\end{array}$ & UN (United Nations) \\
\hline 1979 & $\begin{array}{l}\text { ICOMOS Australia Charter, or Burra Charter - Charter for } \\
\text { the Conservation of Places of Cultural Significance, }\end{array}$ & $\begin{array}{l}\text { ICOMOS (International Council for } \\
\text { Monuments and Sites) }\end{array}$ \\
\hline 1990 & $\begin{array}{l}\text { Charter for the protection and management of the } \\
\text { archaeological Heritage }\end{array}$ & $\begin{array}{l}\text { ICOMOS (International Council for } \\
\text { Monuments and Sites) }\end{array}$ \\
\hline 1993 & $\begin{array}{l}\text { Guidelines for Education and Training in the Conservation } \\
\text { of Monuments, Ensembles and Sites }\end{array}$ & $\begin{array}{l}\text { ICOMOS (International Council for } \\
\text { Monuments and Sites) }\end{array}$ \\
\hline 1995 & $\begin{array}{l}\text { Convention on Stolen or Illegally Exported Cultural } \\
\text { Objects }\end{array}$ & $\begin{array}{l}\text { UNESCO UNIDROIT (United } \\
\text { Nations Education \& Scientific } \\
\text { Organization) }\end{array}$ \\
\hline 2003 & Sustainable Development Framework & $\begin{array}{l}\text { ICMM (International Council on } \\
\text { Mining and Minerals) }\end{array}$ \\
\hline 2005 & Lao Law on National Heritage & $\begin{array}{l}\text { Lao PDR (Lao People’s Democratic } \\
\text { Republic) }\end{array}$ \\
\hline 2006 & $\begin{array}{l}\text { IFC ISO14001: Performance Standards on Biodiversity } \\
\text { Conservation and Natural Resource Management }\end{array}$ & $\begin{array}{l}\text { IFC-World Bank (International } \\
\text { Finance Corporation) }\end{array}$ \\
\hline 2012 & $\begin{array}{l}\text { IFC Environmental and Social Policy and Performance } \\
\text { Standards }\end{array}$ & $\begin{array}{l}\text { IFC-World Bank (International } \\
\text { Finance Corporation) }\end{array}$ \\
\hline
\end{tabular}

Table 1 Key International and National Policy and Regulation that have informed development of the Sepon Cultural Heritage Management Plan and Cultural Heritage Management Program at the Sepon Mine.

\section{Regulatory Processes for the Management of Cultural Heritage at the Sepon Mine}

The Sepon Mine was considered by the World Bank to apply "a strict regime of environmental standards, procedures and practices” (World Bank 2006: 18) to reduce the risk of social, cultural and environmental impacts from mining. From its inception, the Sepon Mine applied an Environmental and Social Impact Assessment (ESIA) process to meet international regulations and standards for 'best practice' environmental and social management. The Sepon Mine initially received support from the International Finance Corporation, the investment division of the World Bank, who initiated the implementation of regularly processes as a requirement for the mine to be approved (McGuire \& Reimann 2011). The ESIA frameworks applied at the Sepon Mine followed international frameworks with baseline studies that included preliminary heritage surveys to determine any cultural and historical significance located within the Sepon Mine, and the actual and potential social and environmental impacts of the mine. In total six ESIAs were undertaken between 2001 and 2011 as mining expansion grew (McGuire \& Reimann 2011). Several rounds of cultural heritage assessments and socio-cultural surveys of communities within the mining tenement area were undertaken, including one large-scale survey of local intangible heritage values and practices, and extensive archaeological surveys and excavations.

A formal Cultural Heritage Management Program was established at the Sepon Mine around 2008 to manage an increasing amount of cultural heritage materials being identified. The Cultural 
Heritage Management Program (CHM Program) was run by Lao Government archaeologists from the Department of National Heritage, Lao PDR, and later through a joint Lao-Australian collaboration with James Cook University. The CHM Program provided support to upgrade the preexisting cultural heritage management system by providing "codes of practices and standard operating procedures for the location, recording and protection of cultural heritage” (Oz Minerals 2008: 57). The system upgrade centred on establishing a new Cultural Heritage Management Plan in 2010 to enhance heritage protection by promoting heritage management activities as part of operational procedures at the Mine. This would centre on formalising procedures and guidelines for archaeology and cultural heritage management practices during mining operations. Procedures and guidelines were based on international industry 'best practice' approaches, notably the ICOMOS Australia Burra Charter, and Lao heritage policy and national legislation, principally the 2005 Lao Law on National Heritage (see Table 1). The value of cultural heritage was based on a tiered system of local, national, and international significance, and heritage was defined as either natural heritage, or tangible, intangible or historical cultural heritage

The Cultural Heritage Management Plan also outlined the processes and guidelines for managing identified cultural heritage sites, heritage site monitoring processes, reporting procedure associated with the findings or outcomes of monitoring activities, and the process for registering archaeological and cultural heritage sites in a database. It also initiated a company-wide training and awareness program for all Sepon Mine staff, consultants, and contractors about local cultural heritage and appropriate management of cultural heritage (MMG-LXML 2010). The database of registered archaeological and cultural heritage sites was developed to contain an inventory of sites and objects identified or collected during management and monitoring activities. Identified cultural heritage sites were assigned specific management activities based on their level of significance and need for mitigation strategies from mining-based impacts. Levels of significance identified for each site or object were categorised as low, medium, and high significance, and based on consultation with local stake holders and heritage specialists or consultants. Site management and monitoring processes were implemented at sites considered 'High Significance', with processes for management and monitoring determined on a case by case basis at each site or location (see Table 2).

No explicit management protocols were assigned to 'natural heritage' at the Sepon Mine. The Cultural Heritage Management Plan identified 'natural' heritage as a category, as well as the need to identify and protect natural heritage and the potential for a relationship between cultural and natural heritage to exist. Rather, the Department of Environment that coordinated and managed environmental protection, regulated by its own Environmental Management Plan. As with the Cultural Heritage Management Plan, the Environmental Management Plan was developed from several national and international laws, guidelines and industry 'best practice' regulatory standards. In particular, international certification under the IFC ISO14001: Performance Standards on Biodiversity Conservation and Natural Resource Management, ISO14001, and IFC Environmental and Social Policy and Performance Standards, guided the principles and processes for the environmental management system at the Sepon Mine. 


\begin{tabular}{|c|c|c|c|c|}
\hline $\begin{array}{l}\text { Name of } \\
\text { Cave }\end{array}$ & $\begin{array}{c}\text { Identified Heritage } \\
\text { Values }\end{array}$ & $\begin{array}{l}\text { Heritage Significance } \\
\text { Classification }\end{array}$ & Identified Impacts & Management Strategy \\
\hline $\begin{array}{l}\text { Tiger -Cave } \\
\text { Mountain }\end{array}$ & - & - & - & $\begin{array}{l}\text { Cave has been fenced off } \\
\text { by village for preservation }\end{array}$ \\
\hline $\begin{array}{l}\text { Tham Pha (Pha } \\
\text { Ong Saen) }\end{array}$ & $\begin{array}{l}\text { Historical Significance } \\
\text { (Buddhism) }\end{array}$ & High Significance & - & - \\
\hline Tham Nam & Natural Scenic Beauty & $\begin{array}{l}\text { Significant Heritage Site } \\
\text { (Natural Scenic Beauty) }\end{array}$ & - & - \\
\hline Tham Phra & Natural Scenic Beauty & $\begin{array}{l}\text { Natural Significance; Historical } \\
\text { Significance; Cultural } \\
\text { Significance (present use) }\end{array}$ & - & - \\
\hline Tham Ke & Natural Scenic Beauty & $\begin{array}{l}\text { Natural Significance; Historical } \\
\text { Significance }\end{array}$ & - & - \\
\hline $\begin{array}{l}\text { Tham Phra } \\
\text { (Keng-Lek) }\end{array}$ & Cultural Significance & Significant Heritage Site & - & - \\
\hline Tham Kek & $\begin{array}{l}\text { Legacy of the Indochinese } \\
\text { War }\end{array}$ & Significant Heritage Site & - & - \\
\hline $\begin{array}{l}\text { Tham } \\
\text { Posaenphanh }\end{array}$ & $\begin{array}{l}\text { Legacy of the Indochinese } \\
\text { War }\end{array}$ & Significant Heritage Site & Looting and unauthorized archaeological excavation & $\begin{array}{l}\text { Proposed Monitoring by } \\
\text { National and Vilabouly } \\
\text { District Government }\end{array}$ \\
\hline $\begin{array}{l}\text { Tham Phra } \\
\text { (Nagachahn) }\end{array}$ & Natural Scenic Beauty & Significant Heritage Site & - & 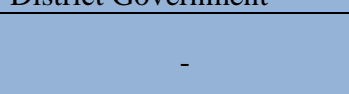 \\
\hline Tham Seua & $\begin{array}{l}\text { Legacy of the Indochinese } \\
\text { War }\end{array}$ & - & - & - \\
\hline Tham Bing & - & $\begin{array}{l}\text { High Significance Cultural } \\
\text { Heritage Site }\end{array}$ & $\begin{array}{l}\text { The cave is likely to face issues relating to artificially lowering the } \\
\text { water table as the Phavat North mine digging continues }\end{array}$ & $\begin{array}{l}50 \text { metre buffer-zone } \\
\text { around the cave and water. } \\
\text { Managed by Heritage and } \\
\text { Environment Units }\end{array}$ \\
\hline Tham Pakou & - & $\begin{array}{l}\text { High Significance Cultural } \\
\text { Heritage Site }\end{array}$ & $\begin{array}{l}\text { Possible impacts from exploration and mining activities in the local } \\
\text { area of which is now only } 500 \text { metres east of the cave site. The area } \\
\text { of the cave has been opened up to outsiders due to mining } \\
\text { exploration tracks and roads }\end{array}$ & $\begin{array}{l}\text { Site-Specific Management } \\
\text { Plan }\end{array}$ \\
\hline
\end{tabular}

Table 2 Caves within the Sepon Mine managed by the Cultural Heritage Unit as part of mining operations. Caves are listed based on Value, Significance, Impacts, and Management Strategy. 


\begin{tabular}{|c|c|c|c|c|}
\hline $\begin{array}{l}\text { Name of } \\
\text { Cave }\end{array}$ & $\begin{array}{l}\text { Identified Heritage } \\
\text { Values }\end{array}$ & $\begin{array}{l}\text { Heritage Significance } \\
\text { Management } \\
\text { Classification }\end{array}$ & Identified Impacts & $\begin{array}{l}\text { Identified } \\
\text { Management } \\
\text { Strategy }\end{array}$ \\
\hline Tham Palon & - & $\begin{array}{l}\text { High Significance Cultural } \\
\text { Heritage Site }\end{array}$ & $\begin{array}{l}\text { It is located in the Sepon Greater Project Development Area there } \\
\text { is risk of future mining-based geological exploration impacts on } \\
\text { the site. The cave site is located approximately } 2 \mathrm{~km} \text { southwest of } \\
\text { the Thengkham project expansion }\end{array}$ & $\begin{array}{l}\text { Site-Specific Management } \\
\text { Plan }\end{array}$ \\
\hline $\begin{array}{l}\text { Tham Bing } \\
\text { Payaeng }\end{array}$ & - & $\begin{array}{l}\text { High Significance Cultural } \\
\text { Heritage Site }\end{array}$ & $\begin{array}{l}\text { The cave site is located approximately } 2 \mathrm{~km} \text { south-west of the } \\
\text { Thengkham project expansion area }\end{array}$ & $\begin{array}{l}\text { Site-Specific Management } \\
\text { Plan }\end{array}$ \\
\hline Tham Latsan & - & $\begin{array}{l}\text { High Significance Cultural } \\
\text { Heritage Site }\end{array}$ & $\begin{array}{l}\text { The cave is located in the SEDA and there is risk of future LXML } \\
\text { geological exploration impacts on the site. The cave is located } \\
\text { approximately } 2 \mathrm{~km} \text { north west of the Greater Project } \\
\text { Development Area }\end{array}$ & $\begin{array}{l}\text { Site-Specific Management } \\
\text { Plan }\end{array}$ \\
\hline Tham Phapoun & - & $\begin{array}{l}\text { High Significance Cultural } \\
\text { Heritage Site }\end{array}$ & $\begin{array}{l}\text { The cave is located in the Sepon Expansion Development Area } \\
\text { and there is risk of future LXML geological exploration impacts } \\
\text { on the site. }\end{array}$ & $\begin{array}{l}\text { Site-Specific Management } \\
\text { Plan }\end{array}$ \\
\hline Tham Hin Keo & - & $\begin{array}{l}\text { High Significance Cultural } \\
\text { Heritage Site }\end{array}$ & $\begin{array}{l}\text { Planned exploration drilling along the top of Thengkham outcrop } \\
\text { will increase access to the site and potentially damage related, } \\
\text { thus so far unrecorded sites }\end{array}$ & $\begin{array}{l}\text { Site-Specific Management } \\
\text { Plan }\end{array}$ \\
\hline $\begin{array}{l}\text { Unknown (cave } \\
\text { name) }\end{array}$ & - & Cultural Significance & - & - \\
\hline Tham Khama & Legacy of the Indochinese War & - & - & - \\
\hline $\begin{array}{l}\text { Tham Pha } \\
\text { Phong }\end{array}$ & Legacy of the Indochinese War & - & - & - \\
\hline
\end{tabular}

Table 2 Caves within the Sepon Mine managed by the Cultural Heritage Unit as part of mining operations. Caves are listed based on Value, Significance, Impacts, and Management Strategy. 
A Cultural Heritage Unit and Cultural Heritage Workshop, established around 2011, provided further support for implementation of the Cultural Heritage Management Plan and CHM Program. The Cultural Heritage Unit was responsible for heritage management activities and was staffed by Sepon Mine staff and staff from the Lao Department of National Heritage. Creation of the Cultural Heritage Unit and Cultural Heritage Workshop supported the on-site heritage management program and an archaeological research program. Importantly, it provided a secure location for artefacts recovered from archaeological excavations (and chance finds), where they could be cleaned, processed, stored, and displayed. The workshop also provided a location for training and capacity development for Lao Government and Lao and Australian student archaeologists, providing 'onthe-job' training and exposure to international archaeological practice and working with Lao national and international experts.

Community relations and environmental management were largely managed separately from the Cultural Heritage Program. The Cultural Heritage Unit was run out of the Department of Social Sustainability (formerly the Community Relations Department), a department established in 2008 to manage community relations and impacts on communities located within the Sepon mine tenement. The Department of Social Sustainability would undertake research to promote awareness and preservation of local livelihoods and intangible cultural heritage as part of their strategy. The Department was largely established to support the Sepon Mine's 'social license to operate' through implementing a social sustainability strategy, to minimise social impacts on the local community in Vilabouly District, and to instigate several benefit-sharing arrangements in an attempt to reduce long-term economic dependence on the mine in preparation for mine closure (McGuire \& Reimann 2011; Neilson 2002). Introduced earlier, the Department of Social Sustainability implemented several socio-cultural surveys of communities within the mining tenement area. The large-scale surveys of local intangible heritage values and practices undertaken there supported a greater understanding of local natural cultural heritage values.

\section{Risk to Heritage within the Sepon Mine}

The Sepon Mine sought to establish a strong basis for heritage protection as part of day-to-day mining operations based on application of international regularity processes, or 'best practice', largely through the ESIA process. Notwithstanding the creation of a formalised policy and regulatory environment to manage heritage, risk of impact to heritage from mining activity generally remained high over the lifetime of the mine (Chamberlain 2007; Mayes \& Chang 2014; Ovesen 2002; Roberts 2019). Overall, little was known about the type and extent of local heritage in Vilabouly District, and mining activity was considered to increase the level of risk of damage or destruction to known and unknown cultural heritage. Arguably, this type of risk could be quantified nationally and regionally, identified in the preamble of the Sepon Cultural Heritage Management Plan which stated that "there is as yet limited knowledge about cultural heritage in Laos and its relationship within the country and as well as across the Asian Region” (MMG-LXML 2010: 31). This knowledge (or lack of it) made effective identification and management of heritage sites and knowledge essential and increased the need for effective mitigation processes to implemented, reviewed, and maintained.

Locally identified risks and challenges to effectively managing heritage at the Sepon Mine were therefore comparable to challenges identified at the regional, national, and international levels. In particular, concerns about the effective implementation and enforcement of environmental and heritage legislation (Neilson 2002), effective application of principles of corporate social responsibility as an industry practice (GIZ \& BGR 2012), and the relationship between socioeconomic development and heritage (Kiernan 2009; Roberts 2015; Sourya et al. 2005) arguably 
increased the level of risk for environmental and social impacts over the lifetime of the mine. To consider in more detail these and other identified risks to heritage at the Sepon Mine, and the processes applied to mitigate heritage from mining-based impacts, the next section will present examples of management procedures and practices for two caves - Tham Pakou and Tham Bing each identified as High Significant Cultural Heritage Sites.

\section{Heritage Management of Caves at the Sepon Mine: A Case Study}

\section{Managing a 'Sacred Natural Site' through Community Consultation at Tham Pakou}

The management process at Tham Pakou provides a good example of the complexities found in managing a natural geological site with overlapping and interconnected cultural uses and values. Further, it highlights the use of a multi-lateral management process coordinated between the Sepon Mine, Vilabouly District Government, and the village authority of Ban Namalou. Tham Pakou is situated within the village landscape of Ban Namalou, a majority Makong speaking group (MonKhmer) at the southern foothills of the Thengkham Range. Tham Pakou is a highly valued place for Ban Namalou villagers, based on a range of cultural, spiritual, and ecological uses and values. Tham Pakou is recognised by Ban Namalou as a focal place within local belief as the site of the village founder's story. The cave is residence of two spirits - Laung Bang and Laung So (or Su) who are considered by villagers to protect the village and other places within the village boundary, and are called upon for ceremony throughout the calendar year. Residents of Ban Namalou expressed desire to preserve Tham Pakou to protect the spirits, but also to retain the memories of past activities that occurred in the cave, including by Buddhist Monks, and during the Vietnam War (see Figure 2).

During 2009, Tham Pakou became the focus of a community consultation process over mining expansion plans and planned test drilling for copper ore close to this and another cave, Tham Palon. Ban Namalou villagers were consulted about the proposed expansion plans and the potential for exploration drilling near the caves. The consultation process allowed the community to provide feedback about their values for the cave, and aspirations for their future use of the cave. Through the consultation process villagers explained to Sepon mining company representatives they were concerned that any drilling near the caves would impact the cave, in particular, drilling would upset, the ancestral spirits - Laung Bang and Laung So - that villagers explained resided in the cave. This context was articulated by a local villager:

In about 2009, the mining company was planning to perform test drilling here at the location of Tham Pakou. There was a consultation process between village representatives of Ban Namalou and the mine. The village people expressed concern to the mine that we did not want the mining here, that it would disturb the spirits of this cave.

Another community aspiration to manage and protect the cave from impacts was to protect the cave for its past uses, to continue to acknowledge the memory of local community members who died during the Vietnam War. This was explained by another local villager:

We may need to take shelter in here again. For that reason I would like to see more protection of the cave and its environment, and...to remember the war period and those who died during that time. 
The villager's perspectives and aspirations for management of the cave were also underscored by customary rules and obligations around use of natural resources and locations that were forbidden, like the home of mahasak paa or 'spirit forests'. Another Vilabouly resident outlined this situation:

...you need to respect the owners of the area [you are working in] and the past people [who used to live there]. Spirits come to other people not just yourself and they can make you sick or even die. This is not in the scientific way, but in the local beliefs.

Throughout the course of the consultation process, Ban Namalou villagers requested that any planned exploration drilling or other mining activity near the caves be cancelled. Eventually, the consultation process between village representatives and the Sepon Mine led to an indefinite postponement for planned exploration drilling at Tham Pakou. As an outcome to the consultation process, no mining expansion activity took place in the vicinity of Ban Namalou and Tham Pakou since 2009.

Ongoing community consultation process reaffirmed the strong cultural association to the Tham Pakou. In 2012, the cave was made a 'High Significance Cultural Heritage Site' and a site management plan was implemented. Heritage classification took into consideration the villager's cultural cosmology, beliefs, and ritual practices associated with Tham Pakou. Importantly, Tham Pakou was registered as a location that held both tangible and intangible cultural heritage significance, based on the consultation process, and later archaeological surveys and assessments. The significance of the cave was based on the villager's cultural association to the cave as the residence of ancestral spirits, but importantly took into consideration their aspirations for the protection and preservation of the cave and its surrounding environment for present and future uses.

Tham Pakou remained a significant location for Ban Namalou villagers who continued to believe that damage or destruction to the cave would anger the resident spirits, leading to negative impacts on the livelihoods of villagers. However, mine-based management of the cave and the associated ecological and cultural values are identified to remain at risk from broader indirect threats as a result of mining-based activity in the Thengkham Range, largely from the movement of peoples into the mining tenement areas. The identified risk to Tham Pakou and potential for this to impact the cave were outlined in the 2012 cultural heritage assessment of the cave:

Possible impacts from exploration and mining activities in the area... which is now only 500 metres east of the cave site. The area of the cave has been opened up to outsiders due to mining exploration tracks and road (MMG-LXML 2012). 

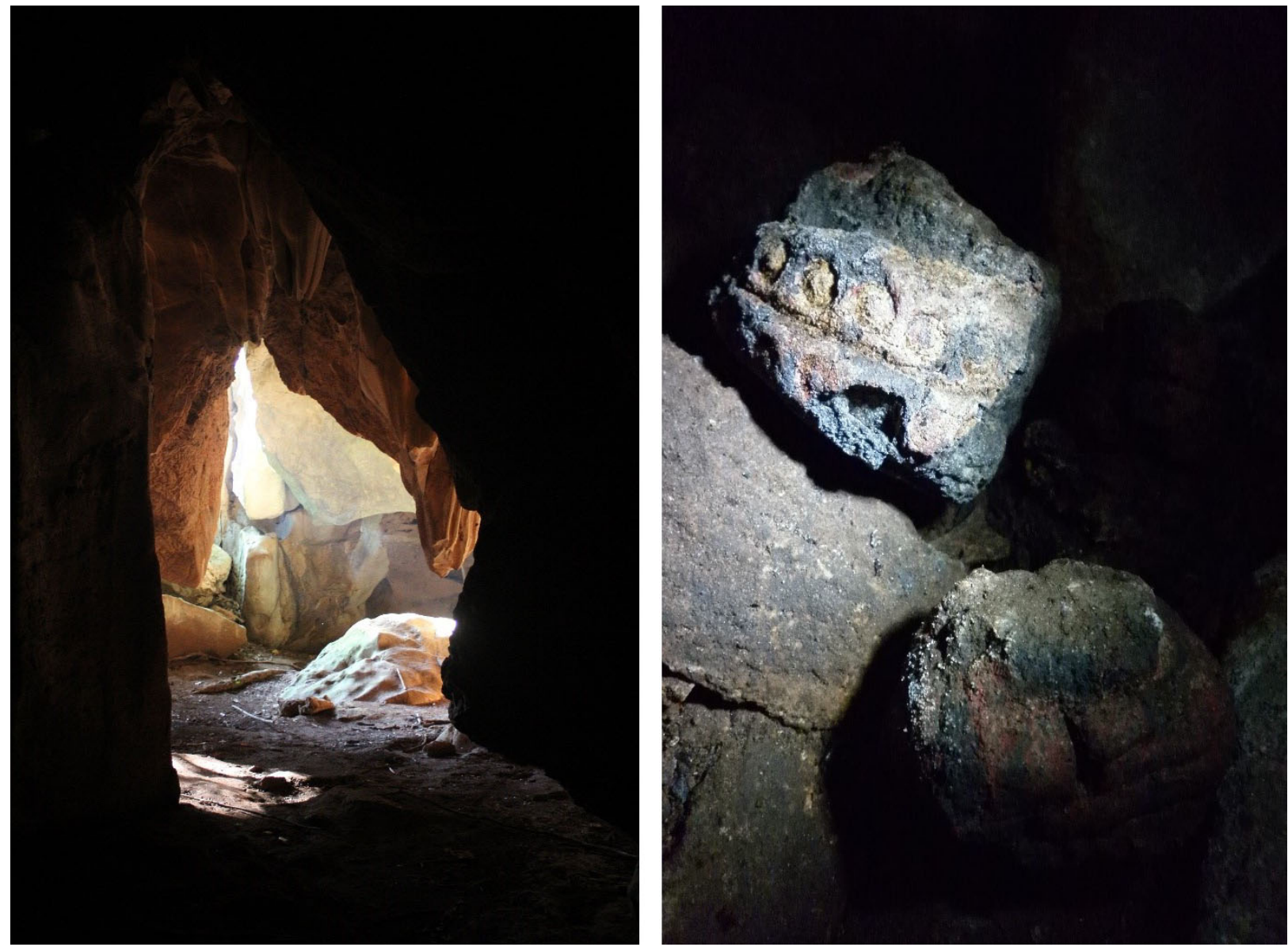

Fig. 2 Tham Pakou - Residence of two spirits: Laung Bang and Laung Su - is significant to the villagers of Ban Namlou (left); Old wood Buddha statues - evidence of earlier occupation of Tham Pakou (right). Source: Nicholas Roberts.

While the consultation process allowed for local villagers to voice their concerns and to provide protective measures for Tham Pakou, ongoing mitigation of impacts to the cave has remained a complex and contested issue. Even though a management process is in place at Tham Pakou, unregulated human activity remained impactful on the surrounding environment, increasing the risk of impact to the heritage values contained within the cave. Impacts from in-migration will be discussed later in this paper, in relation to broader impacts of unsustainable natural resource use, and the outcome this has on local environment and cultural heritage. For now though it is important to state that while Tham Pakou is classified as a 'High Significance Cultural Heritage Site' for its tangible and intangible cultural heritage values, the integrity of these values rely on the natural environment remaining intact. Future impacts or destruction of the natural environment within Tham Pakou and the surrounding Phu Pakou Mountain will impact the intangible heritage values and potentially the livelihoods and wellbeing of Ban Namalou villagers.

\section{Management of Cultural and Natural Heritage through 'Exclusion Zones' at Tham Bing}

The management process at Tham Bing also provides a good example of the complexities found in managing a natural geological site with overlapping and interconnected cultural uses and values. It also highlights the use of a multi-lateral management process coordinated by the Department of Environment the Cultural Heritage Unit respectively within the Sepon Mine, and the village authorities of Ban Namkheun and Ban Boung. Tham Bing is also registered as a 'High Significance Cultural Heritage Site' and has a site management plan. The site-specific management process for Tham Bing is also unique for its use of a 50 metre exclusion or 'buffer' zone around the cave to 
mitigate the impacts from mining activity (see Figure 7). The cave is also monitored on a monthly basis by the Cultural Heritage Unit and the Department of Environment respectively. The Environment Department monitored water levels and water quality to determine the health of the local aquifers beneath the cave, while the Cultural Heritage Unit monitored the cave for impacts from mining and human use.

The 'exclusion zone' at Tham Bing, consists of a pocket of remnant forest made up of tall mature trees and other mixed rainforest vegetation. The 'exclusion zone' is designed to provide a buffer for the cave and concealed it from the outside by providing a protective perimeter to the cave geostructure, and also to the aquifer associated with the cave. To manage impacts to the cave, the exclusion zone prohibited or restricted any human activity within the boundary. This was explained by a staff member, highlighting that approval for access to Tham Bing differ between mine employees and villagers:

Approval needs to be sought from MMG-LXML (Sepon Mine) officials before entering the buffer-zone. Villagers still have access to the cave and its buffer-zone, and do not require obtaining permission from the MMG-LXML officials before entering or using the cave.

The 'exclusion zone' can be accessed by specific Sepon Mine employees with permission and villagers from Ban Namkheun and Ban Boung, as explained above. Villagers of Ban Namkheun and Ban Boung however have largely unrestricted access to Tham Bing and do not need to seek prior approval to enter the cave.

The local uses and values identified at Tham Bing are largely associated with the Vietnam War Period. The cave remains a site of memory for residents of Ban Namkheun and Ban Boung, whose ancestors were reportedly killed at Tham Bing as a result of bombing raids. This history of the cave was explained by a local resident:

The history of the cave is about the Vietnam War period. During this time the cave was used by local people to shelter during the bombing raids.

For villagers of Ban Namkheun and Ban Boung there remains a strong belief that the spirits of dead relatives killed by bombing raids during the Vietnam War still reside there. Villagers engage in the regular processes of ritual activity to propitiate deceased ancestors and other spirits. Several shrines are erected and remain actively used by villagers as part of the memorial process for deceased ancestors (see Figure 3). Shrines were also used to propitiate other local spirits for merit and good fortune. These practices are believed to connect the village to the deceased ancestors and spirits at specific times throughout the calendar year. This was explained by a local resident, who stated:

People here pay respect to the dead here. Even when you sleep (there) the person will come to them in a dream. This is good for people as they can see their ancestors in a dream. If they do something disrespectful to that person (even when they are deceased) they might hear you. They might make you sick or not well. So you go to the cave to respect them. 
Stated earlier, Tham Bing is also identified to hold both natural heritage values and cultural heritage values for villagers of Ban Namkheun and Ban Boung, The forested exclusion zone contained several edible species including wild banana, cassava, and other vegetables that were collected by local villagers. There is a symbiotic relationship between old-growth fig trees and cave geology (see Figure 3), which raised the prospect of World Heritage listings by Sepon Mine staff who considered the natural aesthetics of the cave comparable to other World Heritage sites in Vietnam:

In Vietnam these places are world heritage - why not here? The trees and rocks and their association to each other at the cave is an important thing to this area, and a part of why these places should be protected.

Even though Tham Bing was classified as a 'High Significance Cultural Heritage Site' and a strict management program was in place, the cave was obviously regularly used by people, with over-use or unregulated use having a noticeable effect on the cave environment. Rubbish was a prominent feature at Tham Bing. The upper entrance to the cave and outer area where people where sheltering was heavily littered with food wrappers or containers made of plastic, cigarette packets, garbage bags, and other rubbish items. The rubbish at the cave was openly discussed by Sepon Mine staff during a monthly monitoring processes, however, the rubbish was not removed. Another noticeable human impact at Tham Bing was graffiti written in Lao script, spray-painted in two places on the wall of the first entrance to the cave. Monitoring reports indicated that the graffiti had been on the cave walls for a long period of time. The act of spraying graffiti on the cave walls was also considered to be bad for the cave environment, but the graffiti had not been removed from the cave walls.

Tham Bing was also reportedly being accessed by new populations, including Sepon Mine staff, but also new economic migrants entering Vilabouly District as a result of mining activity. The new and increased use of the cave were seen to increase the physical impact on the cave environment and its surrounding ecology. While it was important that the management regime for Tham Bing has allowed community-based interest and practices to remain ongoing, at the same time unregulated use of the cave by human populations arguably increased risks to the sustainability of the cave environment, the cultural values of the cave, and potentially the use of the cave by future generations. Management protocols were either not being applied or were overwhelmed with overuse of the cave to mitigate impacts, as indicated by management practices appearing ineffective in reducing the damage being generated from mining and associated human activity. 

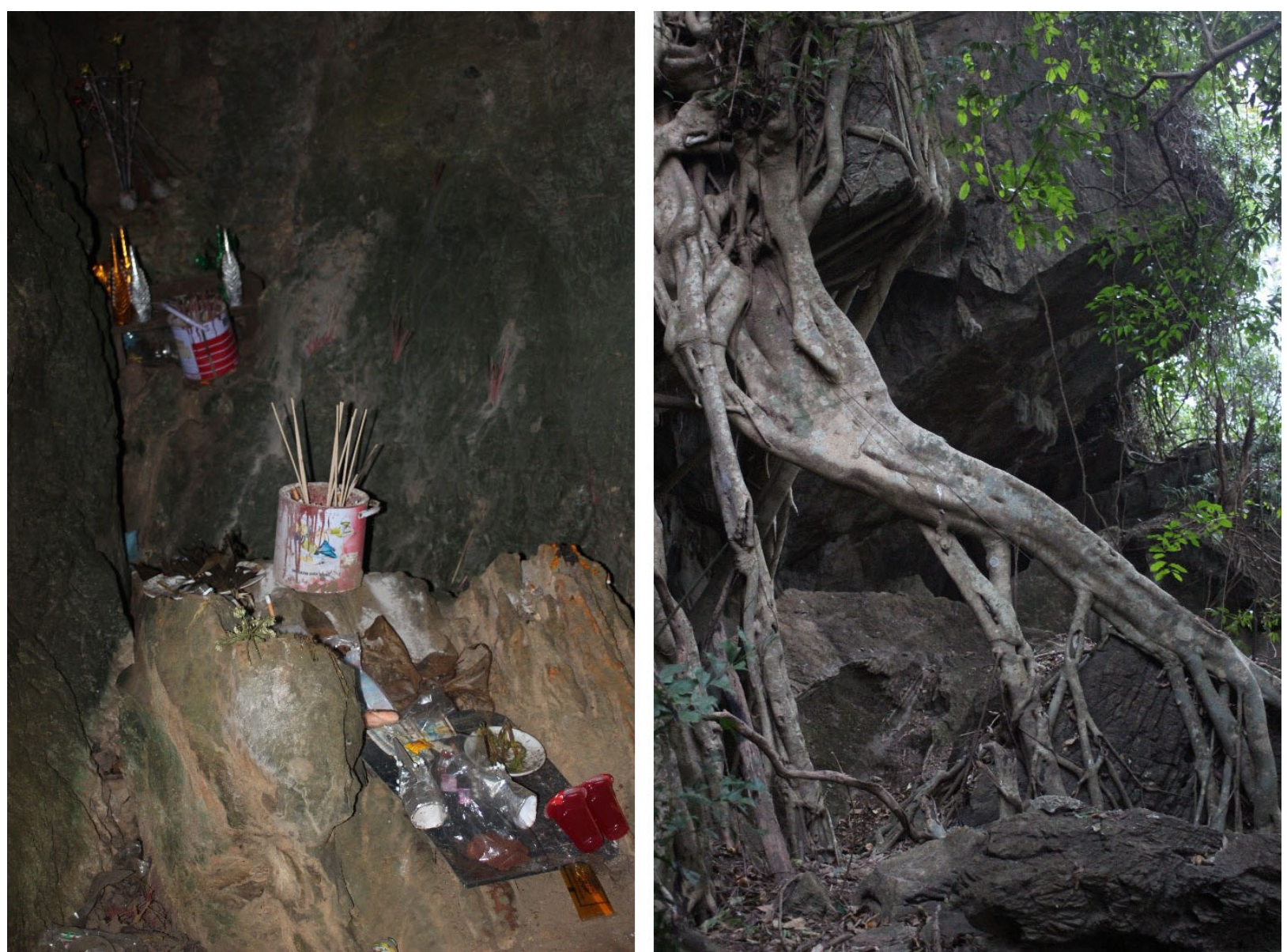

Fig. 3 Shrine to deceased ancestors at Tham Bing (left). Large fig trees straddle the entrance to Tham Bing (Right). Source: Nicholas Roberts.

\section{Heritage Management Challenges within and Beyond the 'Heritage Site'}

\section{Land Tenure, Land Use, and Impacts to Heritage Management}

Impacts to the natural resource base from mining activities within the Sepon Mine bring into consideration the rights and interest present-day local communities have to use and manage natural resources, including caves, and the effectiveness of heritage management practices to support sustainable development of natural places like caves. It has been shown that Brou and Phou Thay people share a close relationship with the natural resource base in Vilabouly District and Thengkham Range area. This relationship is exemplified by exceptional local botanical knowledge, reliance on wild plants and meats for economic and subsistence use, and belief systems where natural places and features within the landscape are imbued with spirits and mythological association. In this context, retaining and transmitting local traditional ecological knowledge is reliant on there being a 'wild' resource. That is, knowledge in this context requires a natural source for knowledge and associated beliefs and practices to be transmitted and maintained, and the source needs the knowledge to maintain its existence. As Ito (2003) has articulated "[i]ntangible culture produces tangible cultural objects which require intangible culture” (n.p). 
To consider in more detail the relationship between people, culture, and nature locally, the Brou ethnolinguistic communities of the Thengkham Range (near where Tham Pakou is located) provide an important example. Brou villages assert ownership over most of the Thengkham Range and display a traditional connection there through historical, economic and spiritual association. Ongoing human relationships with the Thengkham Range is identified by land-tenure systems associated with landscapes and forest resource use, and an association with ancestral spirits that reside within natural places. One example of cultural land use are 'markers' called trai or dtin haiyee, recorded in the Thengkham Range between 2011 and 2013 (see Figure 4). A Vilabouly resident explained the use and meaning of this marker for local Brou and Phou Thay:

The dtin haiyee is a marker of space and ownership by a particular village. The area that was owned is approximately a few hundred metres square...(It) is an old form of marking out boundaries, or laying claim to land for farming, building a house or for (claiming) products from the forest... These markers are used by both Brou and Phou Tai (but the name for them differs in language). People or a person laying claims to land or forest products, and depending on the marker, the claim can be open to negotiation, particularly if the land or product being claimed is not being used (by other villagers). To the Brou they are called trai and to the Phou Tai they are called dtin haiyee

Several other offerings and symbolic markers were observed in the Thengkham Range in the mining pits and along mining haul roads throughout the forest (see Figure 5). Although constructed differently to the one discussed above, it is presumed that the ongoing use of cultural 'markers' functioned in a similar way to the trai or dtin haiyee, indicating that a system of communicating natural resource ownership and use with other villages, and potentially mining staff, remained ongoing in the Thengkham Range.

The Thengkham Range is also a residence for Brou ancestral spirits who dwelt in natural features and places along the range. The presence of ancestral spirits became apparent during archaeological excavations at two sites along the Thengkham Range - Peun Baolo and Thengkham South D which became the location of two spirit possessions during the archaeological excavation season in 2012. Mayes and Chang (2014) have illustrated how Brou villagers were incorporated into a spirit ceremony in 2012 to prevent or manage current and future spirit malevolence that was affecting Sepon Mining staff. The ceremony has been interpreted not as "permission seeking, but actually an alternative source of 'ownership participation' linking ancient heritage with contemporary local user” (Mayes \& Chang 2014: 240). However, it was one of a limited amount of public events that could be considered 'participatory' by Brou persons in the management of heritage in the vicinity of the Thengkham Range (a second time being the Tham Pakou consultation process). Prior to this, incorporation of Brou people in heritage management at the Thengkham Range was limited. Management of archaeological sites in the Thengkham Range was generally controlled by the Sepon Mine, Lao Department of National Heritage, and increasingly Vilabouly District Officials. While Brou people were recognised to have villages or land in the Thengkham Range and were consulted in earlier cultural heritage assessments ${ }^{1}$ they remained conspicuously absent from many negotiations and heritage management processes in that area of the mine. From the perspective of community involvement in the heritage management process, the spirit possessions and subsequent spirit ceremonies were the strongest evidence that local Brou were being engaged.

\footnotetext{
${ }^{1}$ See Chamberlain (2007) and Sayavongkhamdy \& Souksavatdy (2006; 2011)
} 


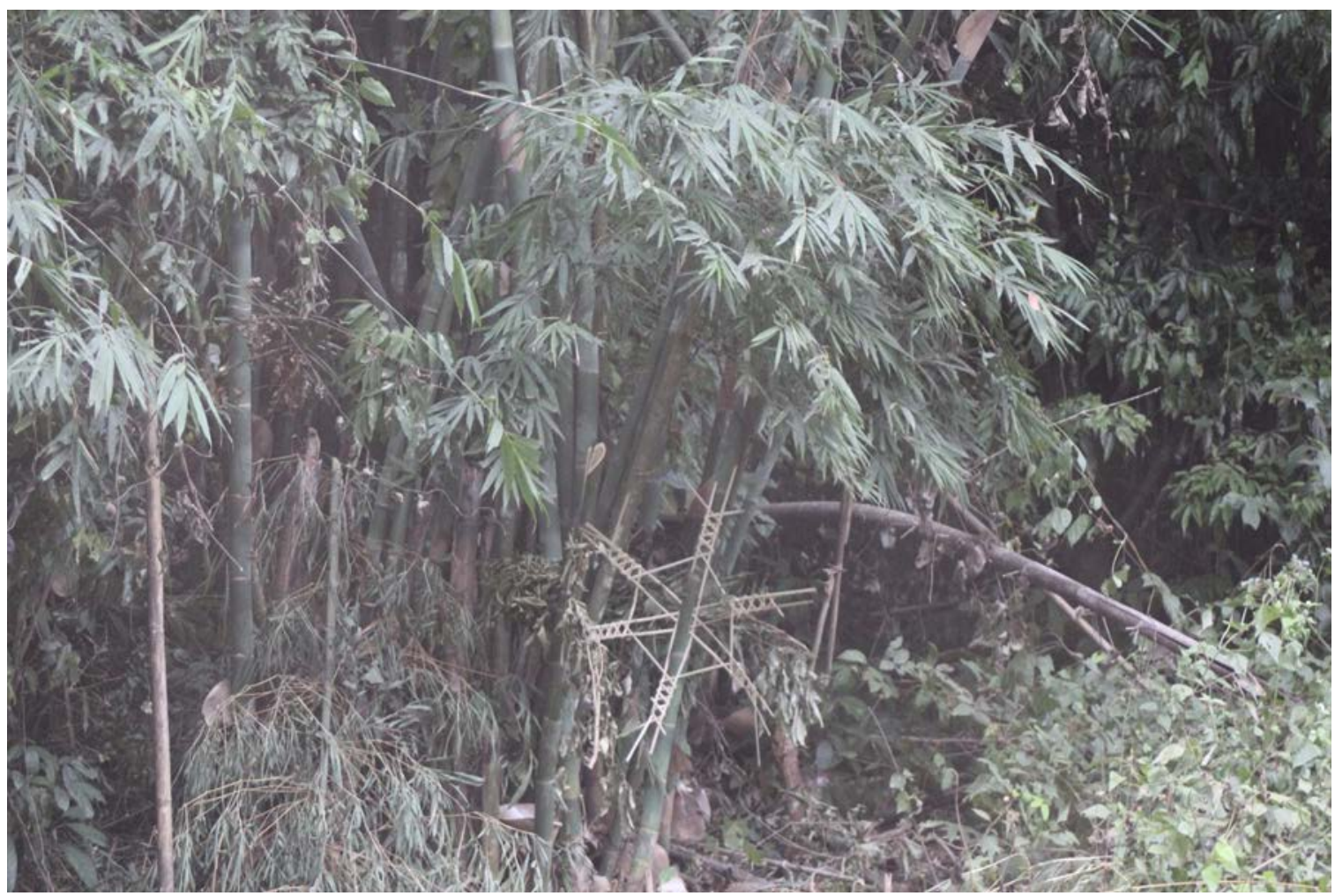

Fig. 4 Dtin Haiyee - boundary or land ownership Marker - Thengkham Range. Source: Nicholas Roberts.

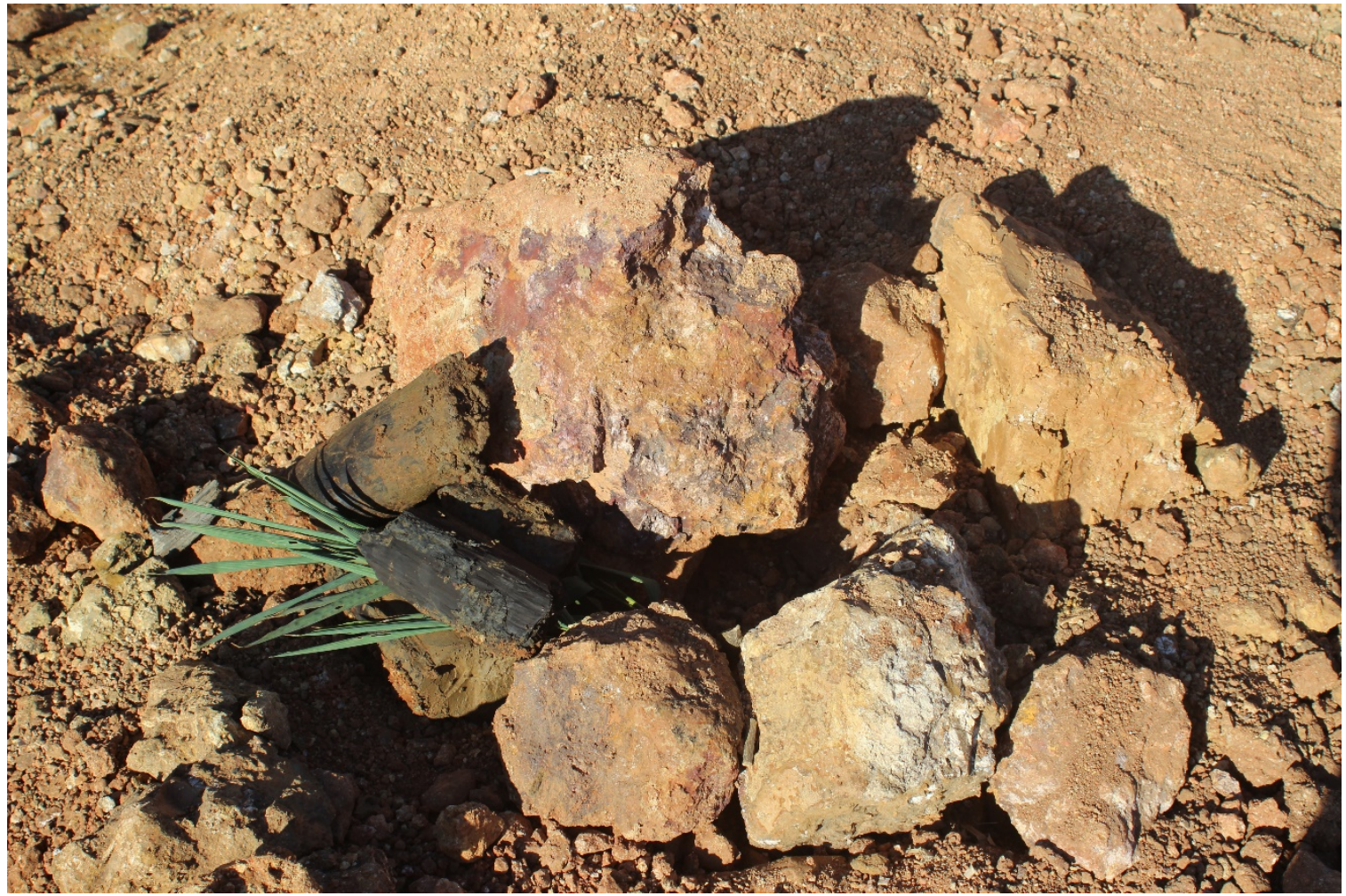

Fig. 5 Offering of excavated wood and forest plants to local sprits at Thengkham South D mining pit. Source: Nicholas Roberts. 


\section{Impacts from In-Migration}

Other threats to heritage and community engagement at the Sepon Mine and greater Vilabouly District were identified as arising indirectly as a result of the mining process. In-migration in particular was identified to have increased the number of non-local Lao persons entering and residing in Vilabouly District to access employment and economic benefits. The presence of the Sepon Mine has supported 'opening up' of otherwise inaccessible landscapes to people from within and outside Vilabouly District, including from Vietnam and other areas of Savannakhet Province. An increase in road construction into previously remote forested areas has greatly supported population movement into previously inaccessible forested areas and into the forests contained within village landscapes. Across tropical Asia, Laurance has highlighted that mineral exploration activities "not only directly destroy or degrade forests, but they also provide a key economic impetus for road-building in forested areas. Such roads greatly increase physical accessibility to forests for colonists, hunters and swidden farmers" (2007: 1547). In Vilabouly District new road development has led to increased competition for use of the natural resource base, including caves, and growth in illegal logging, artisanal and small-scale mining, and over consumption of other natural resources, including bamboo, edible plants, primates, reptiles, and birds.

Increased and largely unregulated human activity in Vilabouly District is identified as one of the most immediate threats to several caves. As the case studies highlight, in-migration is identified as an actual and potential threat to the heritage value of many caves and their surrounding natural environment. In 2012 at Tham Pakou, heritage assessments identified the likelihood of increased impacts due to in-migration, stating that there were several "impacts from exploration and mining activities in the area... which is now only 500 metres east of the cave site. The area of the cave has been opened up to outsiders due to mining exploration tracks and roads” (MMG-LXML 2012). At another nearby cave, Tham Hin Kiaw, potential threats to the cave were identified based on increased access to the cave, stating that "planned exploration drilling along the top of Thengkham outcrop [that] will increase access to the site and potentially damage related, thus far unrecorded, sites” (MMG-LXML 2012). Increased and unregulated in-migration can also be linked to legislation for land use and ownership of resources within a mining tenement area in the Lao PDR. This raises an interesting issue regarding effort to safeguard heritage and ecology by companies and heritage practitioners during the mining process. A Sepon Mine staff member explained this situation:

In Laos there are land ownership laws and as a result villagers and local people can use and/or travel through (mining areas) and take from the forest if they want to. The mine cannot stop them from utilising the forests and riparian systems, neither does the government. As a result relatives of land dwellers (villagers) now come (to the area) to utilise natural resources of relatives village lands

Critically, the national regulations over access and use of land and natural resources within the mining tenement area not only led to impacts on the local ecology and heritage values of Vilabouly District, but also the livelihoods of local community members. This context significantly reduced the Sepon Mine's ability to enforce heritage and environmental management processes and reduce or mitigate impacts, and arguably reduced local economic sustainability. As this and the next section highlight, complex and ineffective governance processes have led to, and were increasingly compounded by, increased flows of people that are progressively threatening local heritage and overburdening the natural resource base. 


\section{Illegal Logging, Wildlife Consumption, and Looting}

Illegal logging and wildlife consumption are activities that arguably have the most noticeable impact to the natural resource base, including caves and other heritage sites within the mining tenement area. In the Thengkham Range, logging has made a conspicuous impact and has contributed to the habitat loss and the reduction of local biodiversity on top of that produced by mining activity. Identified earlier, the loss of natural resources locally increases the risk that cultural knowledge and sites of cultural heritage, both natural and man-made, are impacted or ultimately lost. This causal relationship between ecological destruction and heritage was identified by a Sepon Mine staff member in 2012 as one of the most immediate problems to sustainable environmental management and cultural heritage management in Vilabouly District:

The biggest problem being trees and logging. In the past it was wildlife, which is still an illegal and thriving industry. But most of the primates and larger wildlife, including birds, have been taken

The evidence of ongoing illegal logging was identified around Tham Pakou, and another cave, Tham Hin Kiaw. Often during the archaeological excavation seasons at the archaeological site of Peun Baolo, near Tham Hin Kiaw, chainsaws could be heard cutting down trees, with logs being milled in the forest and later visibly seen being carried out on the back of trucks or motorbikes. Along the forested track that led to Tham Hin Kiaw several large trees lay down in the forest and tree stumps had been cleared with chainsaws, and numerous short-term logging camps could also be identified.

At Tham Pakou and at the base of surrounding Phou Pakou Mountain, illegal logging and deforestation had over time made a significant impact on the surrounding environment (see Figure 6). Illegal logging had resulted in removal of larger old growth trees and vines that once stood at the foot of the mountain, opening up the once closed forest canopy. Logging had also moved closer to Tham Pakou over time and was impacting the location where Asian elephants were identified to travel regularly between 2011 and 2013.

Villagers did voice concerns about the impact that logging occurring adjacent to the cave, the increased hunting of wildlife, and was changing the nature of the cave and surrounding environment within their village lands:

People have begun to encroach closer to the cave and this is a concern. I do not want to see the cave, trees or animals that lived in the area being damaged or destroyed. But logging is getting worse here. You can see the trucks with logs in the backs driving in and out of the forest and the village. There are also piles of logs in the village centre. This is having an impact on the forest close to Tham Pakou 


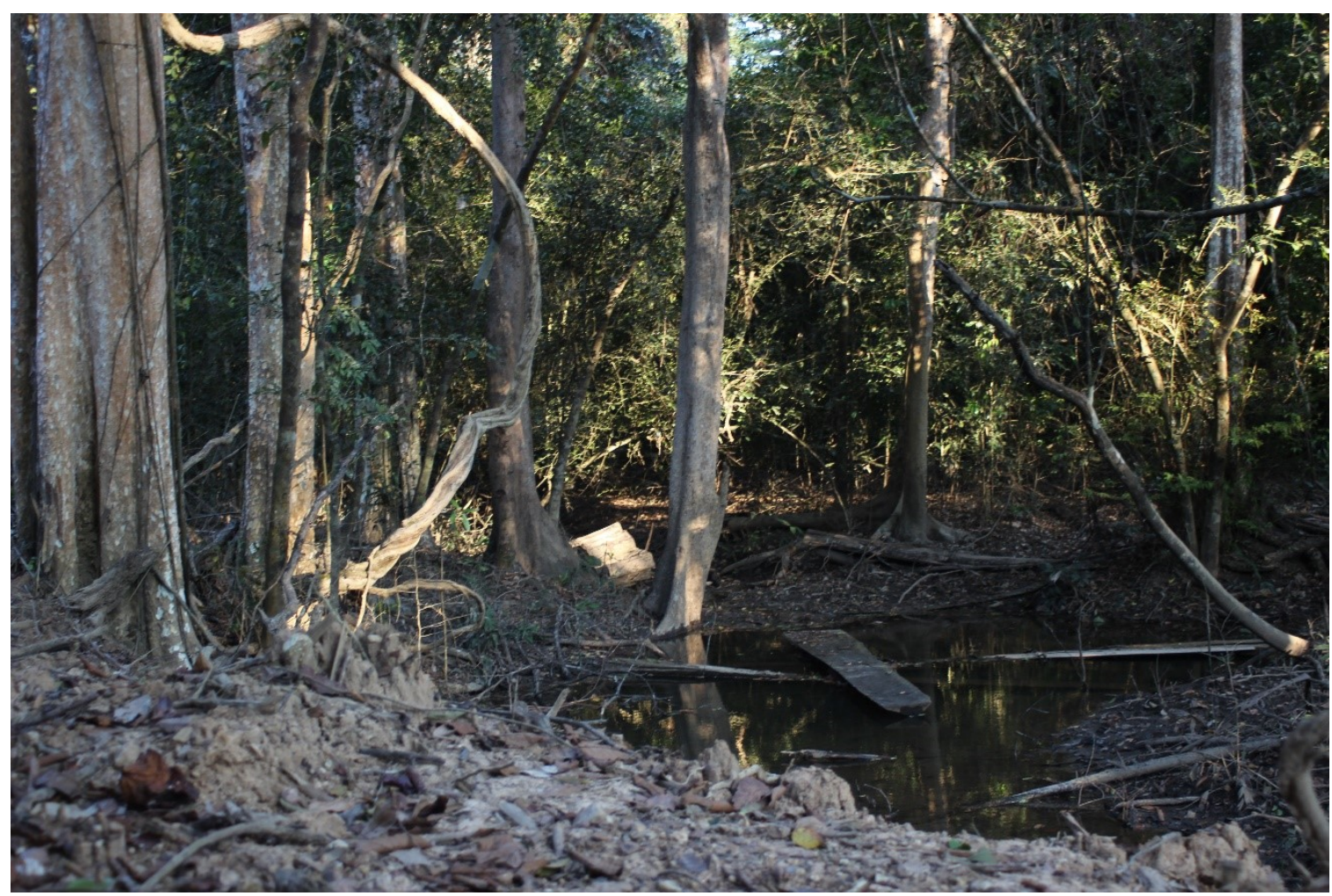

Fig. 6 Impacts from illegal logging adjacent to Tham Pakou. Source: Nicholas Roberts.

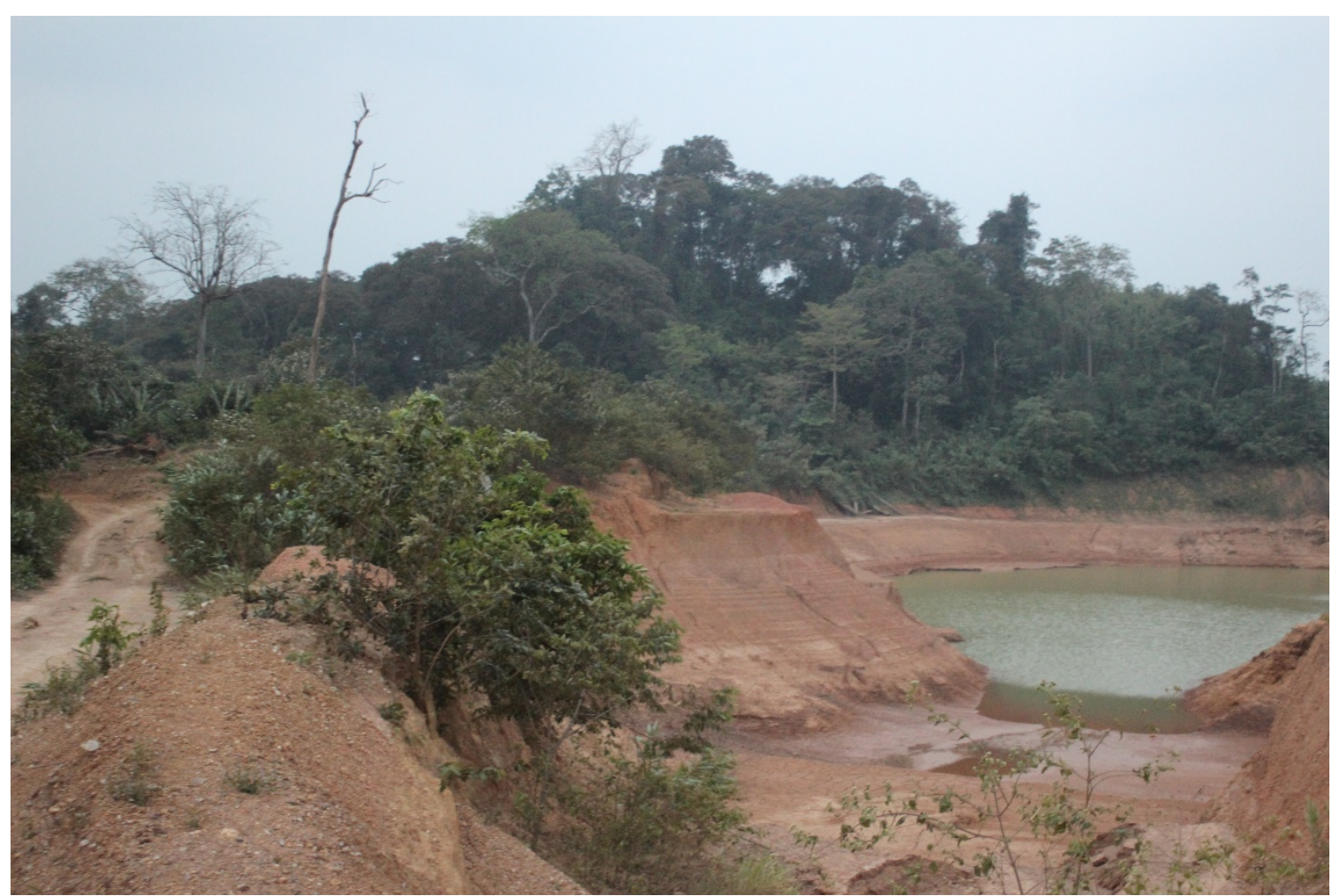

Fig. 7 Mining Impacts on Tham Bing - protected by the exclusion or 'buffer zone' - is surrounded by mining haul roads, pits and water ponds. Source: Nicholas Roberts.

Villagers indicated concern over logging within village lands by stating that felling of trees was not allowed without permission of the village headman. Small-scale logging was originally confined to 
isolated or discreet trees adjacent to the track leading to Tham Pakou, but the scale of the logging had reportedly increasing over time, highlighted by the loss of trees and habitat. This was explained by a villager:

It is becoming more common to see trees like this. But we do know they are not people from Ban Namalou. We are concerned about this. Because people are coming in from outside the village and cutting down our trees. This is not their forest and they do not understand the way it works in Ban Namalou

It was however identified by a Ban Namalou villager that some persons performing illegal logging and using Tham Pakou were from outside the village, but these persons were related to residents of Ban Namalou village:

The people who used the caves had ancestors from the village, so they might not live here in the village now, but their ancestors did. It is the same with people who come here for logging. The same goes for them too. People who come here to cut the trees had connection to the village with ancestors from before, and now they come back and were logging the trees

Increased human activity near Tham Pakou was a complex situation that was also identified to have increased the threat to cultural materials located within the cave. A blue glass bead that was identified in Tham Pakou in previous surveys in 2011 had been taken from within the cave when it was surveyed in 2013. The bead was most likely stolen, and possibly sold to traders like other local historical objects, however this could not be confirmed. The regulatory and statutory processes in place at the Sepon Mine and within Lao heritage legislation are applied to mitigate these impacts. It could be argued that stronger consideration of the indirect impact from mining activity was not applied realistically within management practices, to prevent broader loss of natural resources and heritage sites within the Sepon Mine. Applying management practices that identify how heritage values are not just isolated within caves, but are set within broader ecological, historical and cultural landscapes, is required to provide stronger protection for them within the Sepon Mine and Vilabouly District.

\section{Discussion}

The IUCN recommends that caves and their surrounding ecosystems should be managed for the "full appreciation of all their economic, scientific and human values, within the local cultural and political context” (Waterton et. al 1997: 43). Identification and management of caves based on their broad and interconnected associations is the strongest mechanism to protect caves as geological features that support a range of cultural, economic, and spiritual uses and values. Caves in Vilabouly District hold a range of overlapping, cross-cutting, or interdependent cultural uses and values. From the perspective of international 'best practice' heritage management, Tham Pakou and Tham Bing each have potential to hold tangible, intangible, historical and natural heritage values simultaneously as mixed heritage sites with 'living' and 'sacred' qualities. As a result, they are identified to fulfil, at least to some extent, all the criteria for cultural heritage (tangible, intangible, and historical) and natural heritage protection within the Lao PDR and at the Sepon Mine (see Table 3). In many instances it is the association between types of uses and values that make caves like Tham Pakou and Tham Bing unique as 'living' and 'sacred' places. This involves a complex 
relationship between uses and values in the past, and present and future-intended uses and values. Notwithstanding the variety of heritage uses and values identified, caves within the Sepon Mine are generally managed as cultural heritage sites, managed for mostly tangible heritage values, based on management through largely 'Eurocentric' and archaeological methodologies.

Kiernan (2015) explains that "[a]ccommodating cultural heritage within the criteria used to identify and manage natural heritage properties, and vice versa, needs to be made explicit” (p. 190) in management practices. If all values identified are not made explicit in management regimes, then one or more values are often prioritised at the expense of the others. At the Sepon Mine, the potential for natural heritage to overlap with cultural heritage values was recognised in the Cultural Heritage Management Plan, which also identified the potential for collaboration between departments to management heritage more effectively:

The CHMP lends it support to these efforts when an element of the natural environment becomes recognized for its high cultural heritage significance making it a form of natural heritage in line with the Law on National Heritage of the Lao PDR.

There is potential for overlap between departments in management of heritage sites at the Sepon Mine, notwithstanding, environmental, social, and cultural heritage assessments were for the most part conducted independently. Environmental surveys and management are performed by staff in the Department of Environment or by external consultants; social impact assessments principally undertaken by the Department of Social Sustainability or consultant anthropologists; and cultural heritage assessments and management performed by Lao Government archaeologist and international archaeologists, run out of the Cultural Heritage Unit. The division of roles arguably had an impacts on how effective management of heritage was during mining operations. As one Sepon Mine staff member outlined:

We are trying to manage the impact on heritage here during mining operations. But the two divisions do not often interact on projects or day-to-day operations outside of the Social Sustainability Department assisting to manage and run archaeological projects on site. Sometimes we send members of our team out to work with the archaeological excavations, but members of your team [cultural heritage] rarely work with us. 


\begin{tabular}{|c|c|c|c|c|}
\hline \multirow{2}{*}{ Cave } & \multirow{2}{*}{ Natural Heritage } & \multicolumn{3}{|c|}{ Cultural Heritage } \\
\hline & & Tangible Heritage & Historical Heritage & Intangible Heritage \\
\hline $\begin{array}{l}\text { Tham } \\
\text { Pakou }\end{array}$ & $\begin{array}{l}\text { Local karst geodiversity, } \\
\text { supporting local biodiversity } \\
\text { and water systems } \\
\text { Source of forest products } \\
\text { (animal/plants) for } \\
\text { subsistence } \\
\text { Source of intermittent shelter } \\
\text { for Ban Namkheun and Ban } \\
\text { Boung villagers, and other } \\
\text { local and non-Local Lao } \\
\text { people } \\
\text { Potential source of copper } \\
\text { ore (malachite) used for } \\
\text { modern mining processes }\end{array}$ & $\begin{array}{ll}\text { - } & \text { Source of intermittent shelter } \\
\text { and products (animal/plants) } \\
\text { for subsistence } \\
\text { - } \\
\text { hvidence for current } \\
\text { habitation by Ban Namalou } \\
\text { and non-local Lao persons } \\
\text { - } \quad \begin{array}{l}\text { Potential Prehistoric } \\
\text { Occupation }\end{array} \\
\text { - } \quad \begin{array}{l}\text { Remains of Iron Age material } \\
\text { culture }\end{array} \\
\text { - Remains of Buddhist Period } \\
\text { material culture and habitation } \\
\text { Remains of Vietnam War } \\
\text { period material culture and } \\
\text { habitation } \\
\text { Current residence of Ban } \\
\text { Namalou village guardian } \\
\text { spirits }\end{array}$ & $\begin{array}{l}\text { Material residue and site for } \\
\text { the 'Memory' of Vietnam } \\
\text { War period }\end{array}$ & 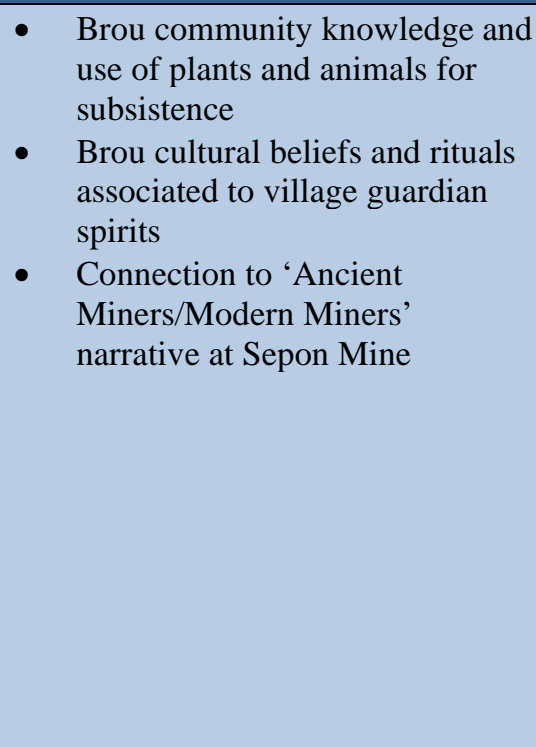 \\
\hline $\begin{array}{l}\text { Tham } \\
\text { Bing }\end{array}$ & $\begin{array}{l}\text { Local karst geodiversity, } \\
\text { supporting local biodiversity } \\
\text { and water systems } \\
\text { Source of intermittent shelter } \\
\text { for Ban Namkheun and Ban } \\
\text { Boung villagers, and other } \\
\text { local and non-Local Lao } \\
\text { people } \\
\text { Cave and surrounding } \\
\text { environment a source of } \\
\text { forest products } \\
\text { (animals/plants) for } \\
\text { subsistence }\end{array}$ & $\begin{array}{l}\text { - Location of Buddhist and } \\
\text { Animist Shrines } \\
\text { Location for Ban Namkheun } \\
\text { and Ban Boung villagers } \\
\text { shrines to deceased relative of } \\
\text { the Vietnam War }\end{array}$ & $\begin{array}{l}\text { - Site for the 'Memory' of } \\
\text { Vietnam War period }\end{array}$ & $\begin{array}{l}\text { - } \quad \text { Current residence of deceased } \\
\text { ancestor spirits killed during } \\
\text { Vietnam War period } \\
\text { Memory and stories of deceased } \\
\text { relatives of the Vietnam War } \\
\text { Phou Thay community } \\
\text { knowledge and use of plants and } \\
\text { animals for subsistence at the } \\
\text { cave } \\
\text { Connection to 'Ancient } \\
\text { Miners/Modern Miners' } \\
\text { narrative at Sepon Mine }\end{array}$ \\
\hline
\end{tabular}

Table 3 Heritage Values of Tham Pakou and Tham Bing based on International 'best practice’ methodology (Compiled by The Author). 
From the perspective of managing cultural heritage, a primary focus on tangible heritage and archaeological research dominated management practice and ideology at the Sepon Mine. Mayes and Chang (2014) observed that "interest at the mine has always gravitated towards the 'tangible' material artefacts and sites rather than the living cultures of the area. This is despite the importance of cultivating good relations with contemporary communities” (p. 240). A primary focus on tangible heritage management is recognised to be common at the international and national levels. Brockwell et al. (2013) have illustrated that overcoming the 'tangible heritage bias' remains a major factor in efforts to move away from Eurocentric heritage discourse and practices in heritage management internationally. The application of scientific archaeological research and archaeological heritage management practice as the principal mechanism to identify and manage heritage led to ongoing identification and management of sites with 'mixed' heritage values, like caves, being classified and managed as either natural heritage, or tangible, intangible, and historical cultural heritage respectively (Bryne 1991; Smith 2006). That said, Mayes and Chang (2014) have highlighted that the "bias towards the material was remedied by the commissioning of a crosscultural ethnographic team to conduct independent surveys in near-mine communities of village histories, folk tales, ritual ceremonies and music” (p. 240). At the Sepon Mine the identification and collection of local intangible cultural heritage was innovative in the context of mining, but survey outcomes were not clearly incorporated into processes for the management of heritage.

The use of consultants, researchers, and the role of the 'expert' in archaeology and cultural heritage management also raises issues with interpretation and local control of heritage knowledge.

Throughout the heritage management process it was identified that the value and meaning of places and objects differentiated between heritage practitioners and archaeologists, and local villagers. In most instances local community members considered 'archaeological objects' heirlooms, with these objects handed between family members over generations. For example, stone adzes were described by villagers as objects that fell from the sky, and were evidence of the presence of ancestors, and were imbued with magical powers that gave the owner luck and power. While the local significance and value of 'archaeological' objects was taken into consideration, items were mostly recorded and presented as 'archaeological artefacts'. The local emic interpretation and value of some places and objects were recorded, but were not generally applied within management processes. Byrne (2013: 165-166) discusses this topic within a regional Southeast Asian context, stating:

Western conservationists, though they may not themselves believe in the supernatural force of the old temple building or the sacred grove, nevertheless will often acknowledge local belief in this force and will try to make allowance for it in their management prescriptions. However, even where this is the case...the conservationist's focus still tends to be solidly on the tangible materiality of the building or grove

All values, significance, and explanations recorded and presented by heritage practitioners and archaeologist should ideally include or represent community beliefs and practices, and not be reinterpreted as 'archaeological artefacts' or 'heritage sites' only. The management process should not override local meanings and values or local decision-making about what is valuable and what should be protected, but should consider local beliefs and values equally as important 'heritage' and incorporate them in management planning. Community involvement in 'archaeological' or 'heritage' management practices should aim to move beyond just the identification of sites and their potential past uses and values, towards integrated and collaborative approaches to the heritage management process. 
Engaging local communities and ethnic groups in archaeological research and the heritage management process is generally found to support more comprehensive identification and management of local heritage. Importantly community-based heritage management is considered to challenge the "imposition of authorised accounts and understandings of heritage and archaeology onto Indigenous people” (Smith \& Waterton 2009: 14). As Greer (2010) has shown, a process of collaboration between the researcher and the community can lead to new understanding of archaeological research, including the development of new and locally directed heritage programs. Community involvement in the management process can allow for "the articulation of a number of Indigenous perspectives including the links between cosmology and ritual and landscapes, archaeological sites and artefacts” (Greer 2010: 55).

Research from other archaeological and heritage management project within the Lao PDR also illustrate how the incorporation of multivocal heritage, community value systems and management practices support successful outcomes (Egloff 1997, 2003; Kallen 2004; Marwick et al. 2013). Involvement of the community in archaeological or heritage management practice is considered an important mechanism to not only move beyond uncritical application of 'Eurocentric' models of heritage and top down heritage governance practices, but also to allow the community to respond and engage with the process of heritage and interpretation of what 'heritage' is. In the Lao context, multiple histories and values of multiple actors, from the local community to the national government, are shown to contribute to how heritage is constructed, used, and valued. Kallen (2004) and Karlstrom (2005) have each identified how multiple histories and narratives can be constituted within archaeological places and objects concurrently. Applying multiple or 'plural' significance and meaning of places and objects, they explain, can expand the use of archaeology, the understanding of archaeological sites and objects, and ultimately enhance the effectiveness of cultural heritage management processes.

A community-centric approach to investigate caves locally at the Sepon Mine has broadened the scope and definition of heritage locally by increasing knowledge about the past and present uses of, and value in, the landscape and places and objects contained within it. Local traditional knowledge, essential in supporting the identification of local heritage sites, provided information about the past and present uses of the landscape, making the unseen visible. They provided a broader understanding of processes of place-making, natural resource selection and use, and complex social and cosmological interpretations of environmental niches. Greater recognition and integration of village-level statutory and customary law and local cultural knowledge at the Sepon Mine could enable a more effective and sustainable localised management process, including methods to reduce impacts or threats to the cultural heritage and overall sustainability of natural places like caves. There is clearly a need to recognise the diverse human uses and knowledge of objects or sites as a heritage of local community groups, and equally of humanity. Greater validation of local knowledge systems and support to realistically embed these knowledge, practices, and participation as part of interpretations and explanations of heritage is required to promote sustainable management of local traditional knowledge, practices, and places within mining and extractive industries.

Looking forward, to effectively include multivocal uses and values and the local community within heritage management practices within mining and extractive industries in the Lao PDR and the Southeast Asian region the integration of regionally developed heritage charters and protocols should be considered. The 1994 Yamato Declaration on Integrated Approaches for Safeguarding 
Tangible and Intangible Cultural Heritage, otherwise known as the Nara Document on Authenticity, recognises the relationship between tangible and intangible heritage, and between people, culture, nature, and history and encourages the application of these into heritage management and conservation approaches. The 2001 Hoi An Protocols for Best Conservation Practice in Asia also promote preservation of the authenticity of heritage sites based on incorporating cultural and religious beliefs and practices within heritage management and conservation approaches (UNESCO 2009). The Hoi An Protocols explicitly emphasise the place of the local community within heritage management and conservation practices:

Inhabitants and users of historic districts are key actors in conservation efforts. Their role should be recognized and welcomed in the planning, the implementation and the review phases of that process. Public awareness, information, consultation and participation help the inhabitants understand, share and care for both the heritage values of the historic district, and the necessary conservation measures including the restrictions they might impose on their daily life. Owners and users should be encouraged to use traditional knowledge and ingenuity to provide continuous care of historic buildings and neighborhoods. Voluntary and proactive participation of inhabitants and associations in cooperation of the government should be promoted and supported (ICOMOS 2003: 1).

Incorporating these and other regional charters and protocols with international 'best practice' for heritage management processes could support realistic application of local cultural traditions, beliefs, and practice as part of activities to manage heritage sites and objects. Logan (2001) has acknowledged that within the Asian region "cultural values lead to a different heritage conservation approach - one in which greater importance is given to symbolic values, intangible heritage and traditional artisan skills” (p. 55). Logan's (2001) view also reflects the underlying philosophical or religious worldview in Asia, where impermanence and material decay (Karlstrom 2005; Tunprawat 2009), and skills and knowledge are heritage values, not just only the physical 'fabric' of material culture, but a view of heritage as an integrated and 'living' whole (Logan 2001: 55). The Hoi An Protocols already share foundational elements with the ICOMOS Burra Charter, which is foundational to many national legal and heritage management practices within Southeast Asia, including the Lao PDR and at the Sepon Mine. Applying more culturally-relative aspects of regional charters and protocols into the management of places like caves, should produce heritage management and conservation practices that are more refined and contextually relevant to the Southeast Asian region. This process could also advocate for increased training and skills development in archaeology, heritage management, and conservation at local community and District levels. Within mining and extractive industries, this could provide a mechanism to move beyond dominance of scientific and archaeological heritage management practice as the principal apparatus to manage heritage. For management of caves, consolidation of international 'best practice' with management practices more attuned to the cultural, historical, and ecological context of the Lao PDR and the Southeast Asian region would be a significant step towards engendering realistic community participation while enabling more sustainable management and protection of the unique local and regional 'living' and 'sacred' uses and values these places hold.

\section{Conclusions}

This paper has examined the effectiveness of identifying and managing caves as 'heritage places' within the Sepon Mine, Vilabouly District, Lao PDR, and the processes established and applied to 
manage and mitigate impacts to heritage from direct and indirect mining-based activities. The Sepon Mine has sought to establish a strong basis for heritage protection that over time grew to apply an effective heritage management and archaeological research program. This program supported international regulatory practices like ESIA and applied 'best practice' heritage management built off the ICOMOS Burra Charter, and Lao national heritage legislation and policy. Community consultation and a community-based approach helped to broaden the scope and definition of heritage locally, and supported stronger on-site identification of heritage in some instances. The program also provided for training of Lao national staff and students in archaeological and heritage management practices. However, the application of international regularity processes and 'best practice' followed a largely 'standardised' approach to heritage management, built on the categorical identification and management of caves as either natural heritage, or tangible, intangible, or historical cultural heritage. This was reinforced through the structural operation for heritage management at the mine and through complex and ineffective landtenure arrangements. While the process and method for heritage management was internationally recognised and accepted, this approach to heritage management is considered ineffective for caves which are identified to hold interdependent 'living' and at times 'sacred' qualities. Generally it is not viewed as analogous to community-based belief and practice, notably the complex relationship between nature, culture, and history. Increasing collaboration with local community in the heritage management process within mining and extractive industries, and applying more culturally-relative protocols like the Nara Document and Hoi An Protocols as part of the regulatory process could provide a mechanism to move beyond reliance on the international heritage discourse and practices as the principal apparatus to identify and manage heritage. This approach would be the most likely method to refined and make more contextually relevant heritage management and conservation practices better suited to the Lao PDR and Southeast Asian region, and could generate firmer support and protection for places like caves and the unique uses and values they support.

\section{Acknowledgements}

Special thanks to Sommay Singthong for the translation of the abstract and title into Lao.

\section{References}

Bekken, D, Schepartz, LA, Miller-Antonio, S, Huang Y and Hou, W (2004). Taxonomic Abundance at Panxian Dadong, a Middle Pleistocene Cave in South China. Asian Perspectives, 43(2): 333-359.

Byrne, D (1991) Western Hegemony in Archaeological Heritage Management. History and Anthropology, 5: 269-276.

Byrne, D (2013) The WCPAs natural sacred sites taskforce: a critique of conservation biology's view of popular religion. In: S Brockwell., S O’Connor and D Byrne (eds.) Transcending the culture-nature divide in cultural heritage: Views from the Asia Pacific region. Canberra, Australia: ANU E Press, 157-169.

Brockwell, S, O’Connor, S and Byrne, D (2013) Transcending the Culture-Nature Divide in Cultural Heritage: Views from the Asia Pacific Region. Terra Australis. Volume 36. Canberra, Australia: ANU Press.

Chamberlain, J (2007) Sociocultural survey of Vilabouly district, Savannakhet Province. Unpublished Report prepared for Lane Xang Minerals Ltd. Vientiane, Lao PDR. 
Clements, R, Sodhi, N, Schilthuizen, M and Ng, P (2006) Limestone karsts of Southeast Asia: Imperilled arks of biodiversity. BioScience, 56(9): 733-742.

Culver, DC and Skeet, B (2000) Hotspots of subterranean biodiversity in caves and wells. Journal of Cave and Karst Studies, 62(1): 11-17.

Egloff, B (1997) Practicing archaeology and the conservation of Tam Ting, Lao People's Democratic Republic. Conservation and Management of Archaeological Sites, 2: 163-175.

Egloff, B (2003) Archaeology and the transformation of living heritage places. Indo-Pacific Prehistory Association Bulletin, 23: 173-186.

GIZ \& BGR (2015) CSR in Lao PDR: Baseline assessment of social and environmental regulations \& standards. GIZ: Vientiane, Lao PDR.

Greer, S (2010) Heritage and empowerment: community-based Indigenous cultural heritage in northern Australia. International Journal of Heritage Studies, 16(1-2): 45-58.

ICOMOS (2003) The Hoi An declaration on conservation of historic districts of Asia. https://www.icomos.org/xian2005/hoi-an-declaration.pdf [accessed 03 June 2015].

Ito, N (2003) Intangible cultural heritage involved in tangible cultural heritage, paper presented at 14th ICOMOS general assembly and international symposium: Place, memory, meaning: preserving intangible values in monuments and sites, 27 - 31 October 2012, Victoria Falls, Zimbabwe.

Kallen, A (2004) And through flows the river: Archaeology and the pasts of Lao Pako. Gotab, Stockholm, Sweden: Elanders.

Karlstrom, A (2005) Spiritual materiality: Heritage preservation in a Buddhist world? Journal of Social Archaeology 5(3): 338-355.

Kiernan, K (2009) Distribution and character of Karst in the Lao PDR. Acta Carsologica, 38(1), 65-81.

Kiernan, K (2011) Challenges for environmentally sustainable development of natural resources in the Nam Ou Karst, Northern Laos. Acta Carsologica 40(2): 341-455.

Kiernan, K (2015) Landforms as Sacred Places: Implications for Geodiversity and Geoheritage. Geoheritage 7: 177-193

Laurance, W (2007) Forest destruction in tropical Asia. Current Science 93(11): 1544- 1550.

Lewis-Williams, D (2002) The Mind in the Cave: Consciousness and the Origins of Art. London: Thames and Hudson Ltd.

Logan, W (2001) Globalizing world heritage: world heritage as a manifestation of modernism and challenges from the periphery. In 20th century heritage: our recent cultural legacy: proceedings of the Australia ICOMOS National Conference 2001, 28 November - 1 December 2001, Adelaide: University of Adelaide, 51-57. Available at http://dro.deakin.edu.au/view/DU:30004820 [accessed 22 October 2017].

Marwick, B, Shoocongdej, R, Thongcharoenchaikit, C, Chaisuwan, B, Khowkhiew, C and Kwak, S (2013) Hierarchies of engagement and understanding: Community engagement during archaeological excavations at Khao Toh Chong rockshelter, Krabi, Thailand. In: S Brockwell, S O’Connor and D Byrne (eds.) Transcending the culture-nature divide in cultural heritage: Views from the Asia Pacific Region. Canberra, Australia: ANU Press, 129-140.

Mauret, C (2004) Burials in Caves. In: J Gunn (ed.) Encyclopedia of Cave and Karst Science New York; London: Taylor \& Francis Books Ltd, 167-169. 
Mayes, W and Chang, N (2014) Discovering Sepon: Cultural Heritage and the making of a modern mine. The Extractive Industries, 1: 237-248.

McGuire, G and Reimann, F (2011) Sustainably managing social investment in poor communities surrounding the Sepon operations. In: J Weirtz (ed.) 1st International Conference on Social Responsibility in Mining. Santiago, Chile. November 19-21. Santiago: Gecamin, 1-7.

MMG-LXML (2010). MMG-LXML Sepon cultural heritage management plan. MMG-LXML Ltd. [Unpublished Report].

MMG-LXML (2012) Sites of significance within the Sepon SPDA. MMG-LXML Ltd. [Unpublished Report].

Neilson, J (2002) Technical analysis of environmental and social impacts assessments for oxiana resources n.l / sepon project Lao. Bankwatch. Available at: http://bankwatch.org/documents/technical_analysis_2002.pdf (accessed 04 March 2009).

Ovesen, J (2002). Indigenous peoples and development in Laos: Ideologies and ironies. Moussons, 6: 69-97.

Oz Minerals Ltd (2008) Sustainability report 2008. Melbourne: Oz Minerals.

Roberts, N (2015) The Cultural \& Natural Heritage of Caves in the Lao PDR: Prospects and Challenges Related to Their Use, Management and Conservation. Journal of Lao Studies 5(1): 113-139.

Roberts, N (2019) Bridging the Divide in Heritage? Managing Caves as Heritage Places within the Sepon Gold \& Copper Mine, Lao PDR. PhD Thesis. James Cook University; Townsville \& Cairns.

Sayavongkhamdy, T and Souksavatdy, V (2006) Sites of archaeological and cultural heritage significance within the greater project development area (GPDA) of Sepon operations. [Unpublished Report prepared for Oz Minerals Ltd].

Sayavongkhamdy, T and Souksavatdy, V (2011) Archaeology and sites of cultural heritage significance within the Sepon expanded development area (SEDA) of Minerals and Metals Group-Lane Xang Minerals Limited (MMG-LXML), Lao PDR. Unpublished Report prepared for Lane Xang Minerals Ltd: Vientiane, Lao PDR.

Sidisunthorn P, Gardener, S and Smart, D (2006) Caves of Northern Thailand. Bangkok: River Books.

Smith, LJ (2006). Uses of heritage. London \& New York: Routledge.

Smith, LJ and Waterton, E (2009) Heritage, communities and archaeology. London: Duckworth.

Sourya, P, Keosopha, K and Siseangrat, S (2005) Country paper of the Lao PDR. Background paper presented at the Sub-Regional Experts Meeting in Asia on Intangible Cultural Heritage, 1316 December 2005, Bangkok, Thailand.

Tattersall, I (1998) Becoming human: Evolution and human uniqueness. San Diego: Harcourt Brace \& Company.

Tunprawat, P (2009) Managing Heritage Sites in Mainland Southeast Asia. PhD Thesis. Silapakorn University, Bangkok, Thailand.

UNESCO (2009) Hoi An Protocols for Best Conservation Practice in Asia: Professional Guidelines for Assuring and Preserving the Authenticity of Heritage Sites in the Context of the Cultures of Asia. Paris: UNESCO.

Verschuuren, B, Wild, R, McNeely, J and Oviedo, G (eds.) (2010) Sacred natural sites: Conserving nature and culture. London \& Washington DC: Earthscan. 
Waterton, J, Hamilton-Smith, E, Gillieson, D and Kiernan, K (1997) Guidelines for cave and karst protection. Gland: International Union for the Conservation of Nature (IUCN).

Williams, P (2008) World Heritage caves and karst. Gland: International Union for the Conservation of Nature (IUCN). 